\title{
Estimating uplift rate histories from river profiles using African examples
}

\author{
Gareth G. Roberts ${ }^{1}$ and Nicky White ${ }^{1}$ \\ Received 12 June 2009; revised 28 August 2009; accepted 21 September 2009; published 10 February 2010.
}

[1] We describe and apply a method for estimating uplift rate histories from longitudinal river profiles. Our strategy is divided into three parts. First, we develop a forward model, which calculates river profiles from uplift rate histories. Height variation along a river profile is controlled by uplift rate and moderated by the erosional process. We assume that the erosional process can be represented by a combination of advection and diffusion, which are parameterized using four erosional constants. Second, we have posed and solved the geologically more interesting inverse problem: which uplift rate history minimizes the misfit between calculated and observed river profiles? The inverse algorithm has been tested on synthetic river profiles, which demonstrates that uplift rate histories can be reliably retrieved. Our tests show that the erosional process is dominated by advection (i.e., knickpoint retreat) and that changes in lithology and discharge play a secondary role in determining the transient form of a river profile. Finally, we have inverted river profiles from a series of African topographic swells, namely the Bié, South African, Namibian, Hoggar, and Tibesti domes. Fits between calculated and observed river profiles are excellent. Calculated uplift rate histories suggest that these domes grew rapidly during the last 30-40 million years. Uplift rate histories vary significantly from dome to dome but cumulative uplift histories agree closely with independent geologic estimates.

Citation: Roberts, G. G., and N. White (2010), Estimating uplift rate histories from river profiles using African examples, J. Geophys. Res., 115, B02406, doi:10.1029/2009JB006692.

\section{Introduction}

[2] Convective circulation of the mantle generates dynamic topography at the Earth's surface. Conversely, the spatial and temporal pattern of dynamic topography holds important clues about the physics of convective circulation, which could be difficult to obtain in other ways. Reliable estimates of dynamic topography are hard to obtain for two principal reasons. First, uplift and subsidence of the Earth's surface are predominantly caused by changes in crustal and lithospheric thickness; isolating a small dynamic signal is not straightforward. Second, erosion isostatically amplifies uplift and the resultant denudation is notoriously difficult to measure with an accuracy of better than hundreds of meters. Denudation is often measured using either radiogenic methods (e.g., cosmogenic surface exposure, fission track analysis) or sedimentary compaction methods (e.g., acoustic velocity calculations). In both cases, there are significant tradeoffs between denudation and other parameters (e.g., temperature gradient, initial porosity). Many estimates are spot measurements with poor spatial resolution and there is a pressing need for methods which allow large-scale patterns of dynamic topography to be identified. Away from collisional mountain belts and regions affected by magmatic

\footnotetext{
${ }^{1}$ Bullard Laboratories, Department of Earth Sciences, University of Cambridge, Cambridge, UK.
}

Copyright 2010 by the American Geophysical Union. 0148-0227/10/2009JB006692\$09.00 underplating, long-wavelength surface uplift is a reasonable proxy for convective processes beneath the lithospheric plate. The history of a landscape should therefore contain useful information about convective processes.

[3] Here, we explore how longitudinal river profiles can be used to estimate spatial and temporal changes in surface uplift on a continent-wide scale. The morphology of the Earth's surface is a complicated response to the history of uplift rate and many numerical experiments, which simulate the development of topography and drainage following uplift, have been formulated. Davis [1899] suggested that mountain belts were built by a discrete pulse of uplift and that landscapes went through distinct phases of "youth," "maturity," and "old age." Subsequently, Penck [1953, 1972] described a model of landscape development in which surface topography responds to a sustained period of waxing and waning uplift. It has been recognized that surface topography does not grow indefinitely but is limited by erosional processes and by lithospheric strength [Hack, 1975; Molnar and Lyon-Caen, 1988; England and Jackson, 1989]. In contrast to the models of Davis and Penck, these authors asserted that substantial rock uplift rates can be sustained over significant periods of time, and that, with appropriate boundary conditions, a landscape can reach steady state equilibrium. In regions of active uplift, the configuration of drainage networks ought to yield information about the temporal and spatial variation of uplift rates. In tectonically stable regions where lithology is uniform, we expect drainage planforms to form simple dendritic net- 
works and drainage profiles to grade smoothly down to a reference level (e.g., sea level). Departures from these simple patterns may provide important clues about the history of uplift rate. Unfortunately, spatial and temporal changes in, for example, basin relief, drainage area, runoff, mean temperature, and lithology present important complications [Hovius, 1998; Whipple and Tucker, 1999; Peizhen et al., 2001; Syvitski and Milliman, 2007].

[4] Recent studies have laid the groundwork for extracting rock uplift rates from the shape of a landscape by exploring the theoretical response of channels to variations in rock uplift rate and by analyzing longitudinal river profiles in regions where tectonic uplift rates can be independently estimated [Whipple and Tucker, 1999, 2002; Snyder et al., 2000; Kirby and Whipple, 2001; Lague and Davy, 2003]. In this way, older qualitative models of landscape development have been replaced by quantitative models, which simulate the complicated interaction between landscape growth and erosion on various scales [Kooi and Beaumont, 1994; Whipple and Tucker, 1999; van der Beek et al., 2002; Baldwin et al., 2003]. Against this theoretical and empirical backdrop, there is uncertainty about what can be learnt from river profile analysis. No standard methodology for extracting tectonic information from drainage networks and river profiles exists. Slope-area analyses are often used to extract concavity indices from river profiles and to gauge the degree of equilibration [Schoenbohm et al., 2004; Wobus et al., 2006a]. However, this approach cannot easily be used to determine uplift rate histories.

[5] Over the last 30-40 Myrs, the African landscape has been sculpted by phases of both regional and continentwide uplift, which are controlled by the changing pattern of convective circulation beneath the lithospheric plate [Burke and Gunnell, 2008]. An obvious manifestation of regional uplift is the distribution of magmatic and amagmatic domes which pepper the interior of the continent (Figure 1). River profiles from a selection of these domes have a range of shapes, which probably reflect temporal and spatial changes in tectonic uplift (Figure 2). For example, the Hoggar dome started to grow 30-35 Myrs ago, whereas the Bié dome grew rapidly over the last 5-10 Myrs, which may account for substantial differences between the two sets of river profiles [Burke, 1996].

[6] Our immediate goal is to develop an inverse algorithm which will permit the history of uplift rate to be estimated from a given river profile. We recognize that there are major obstacles. The most important problem concerns the way in which erosion modulates an uplift signal through time and space. The history of erosion depends in turn upon a range of poorly understood processes (e.g., lithologic response, changes in channel width, discharge). We have divided our treatment into three steps. First, we construct a forward model, which calculates river profiles from uplift rate histories. Our forward model is closely based upon published models and we assume that erosion along a river profile is controlled by a combination of knickpoint retreat and diffusion. We explore the parameter space of this forward model and show that it is sufficiently flexible to fit the range of observed river profiles. Second, we develop an inverse algorithm which calculates uplift rate histories by minimizing the misfit between calculated and observed river profiles. This algorithm has been tested on synthetic river profiles, which demonstrates that uplift rate histories can be reliably retrieved. Third, we have used our inverse strategy to extract uplift rate histories from rivers, which drain regional domes in Africa.

\section{A Forward Model}

[7] We require a model which calculates the shape of a river profile as a function of uplift and erosion. It is important that this model is simple enough to capture the essence of the problem. At the same time, it should be sufficiently general to reproduce the complete range of observed river profiles (e.g., Figure 2). Here, we describe a forward model which is similar in many respects to published models, although our formulation differs [e.g., Howard et al., 1994; Rosenbloom and Anderson, 1994; Whipple and Tucker, 1999, 2002; Humphrey and Konrad, 2000; Snyder et al., 2000; Willgoose, 2005; Bishop, 2007; Gasparini et al., 2007; Whittaker et al., 2008]. We assume that changes in height along a river profile are mainly controlled by the history of uplift rate. For simplicity, we assume that the planform of a river profile does not significantly change, that river capture does not occur, that the reference level down to which the river flows is constant, and that the origin of the river source is fixed. The rate of change in elevation, $\partial z / \partial t$, along the profile is given by

$$
\frac{\partial z}{\partial t}=U(x, t)+E(x, t)
$$

where $U$ and $E$ are the rates of uplift and erosion, respectively. In general, $U$ should vary with time and space but we will assume that $U$ is a function of time alone. $E$ acts to lower the height of the river profile and the form that it should take is less clear. We follow Whipple and Tucker [1999], Rosenbloom and Anderson [1994], and others who assume that $E$ varies as a function of $t$ and $x$. Thus

$$
E(x, t)=-v x^{m}\left(\frac{\partial z}{\partial x}\right)^{n}+\kappa\left(\frac{\partial^{2} z}{\partial x^{2}}\right)
$$

where $n$ and $m$ exert an important control on concavity of a river profile and $n$ is typically $1-2$. We assume that $x^{m}$ is a proxy for the discharge of a river, where $x$ is the distance along a river [Hack, 1957; Weissel and Seidl, 1998]. Note that Whipple and Tucker [1999] use $A^{\hat{m}}$ as a proxy for discharge, where $A$ is the upstream drainage area at any position $x$. If drainage area has an aspect ratio of $\sim 1$ then $\hat{m} \sim 0.5 \mathrm{~m} . \hat{m}$ is typically $0.35-0.6$ [e.g., Schoenbohm et al., 2004]. For African river profiles, comparison of the two proxies show that our simpler description is adequate; it has the important advantage of easy implementation. If $n=1$ and $m=0$, then $v$ is the advective (i.e., knickpoint) velocity. If $n \neq 1$ and $m>0$, the advective velocity is a nonlinear function of local slope and distance along the river. Together, $n, m$, and $v$ control the value of the advective term, which governs the transient form of a river profile and its knickpoint velocity. This term represents the detachmentlimited system discussed by Whipple and Tucker [2002]. Crosby and Whipple [2006] show that knickpoint retreat velocities vary by 5 orders of magnitude (i.e., $1-10^{4} \mathrm{~cm} \mathrm{y}^{-1}$ ). 


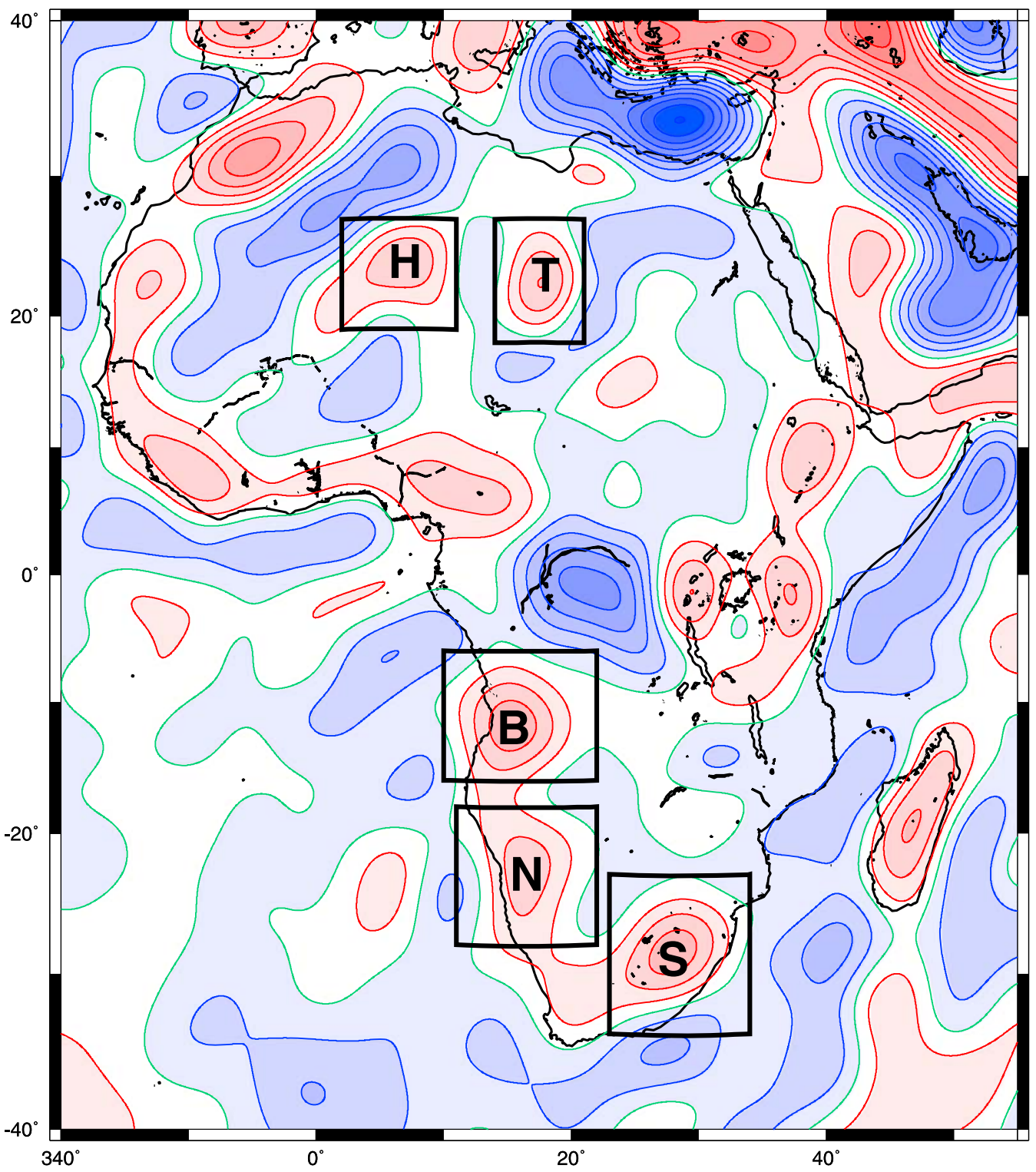

Figure 1. Map of Africa which shows long wavelength $(>800 \mathrm{~km})$ free-air gravity anomalies extracted from GRACE data set [Tapley et al., 2005]. Red, green, and blue shaded contours represent positive, zero, and negative gravity anomalies, respectively. Contour interval is $5 \mathrm{mGal}$. Pattern of longwavelength gravity anomalies probably reflects the pattern of convective circulation beneath the plate. Labeled boxes show topographic swells where river profiles have been analyzed (see Figures 8-12): $\mathrm{H}=$ Hoggar, $\mathrm{T}=$ Tibesti, $\mathrm{B}=$ Bié, $\mathrm{N}=$ Namibian, and $\mathrm{S}=$ South African. The nomenclature of Burke and Gunnell [2008] is used.

Does the advective term need to be so complicated? Howard et al. [1994], Whipple and Tucker [1999], and Tucker and Whipple [2002] suggest that the $n$th power of slope combined with the exponent term $m$ and variable $v$ are required to fit the concavity and transient form of river profiles. Rosenbloom and Anderson [1994] argue that if Playfair's Law applies (i.e., river valleys are proportional to river size and tributaries join trunk streams at the elevation of the trunk stream), then $n=1$ and $m \sim 2$. Here $m$ and $n$ determine the transient form of a profile and could vary from place to place.

[8] Rosenbloom and Anderson [1994] observed that channel convexities relax with distance upstream which suggests that river profiles erode synchronously along their length. This observation prompts the inclusion of a diffusive term, which is a simplified form of the transport-limited system [Whipple and Tucker, 2002]. Here $\kappa$ is erosional diffusivity, which we assume does not vary along the river profile.

[9] The forward model outlined here is based upon a straightforward premise: longitudinal river profiles are principally controlled by the history of uplift rate and on long timescales $\left(10^{5}-10^{6}\right.$ years) the moderating effects of erosion can be approximated by a combination of advection and diffusion (Figure 3). There is considerable debate about the role that different physical processes play in landscape 

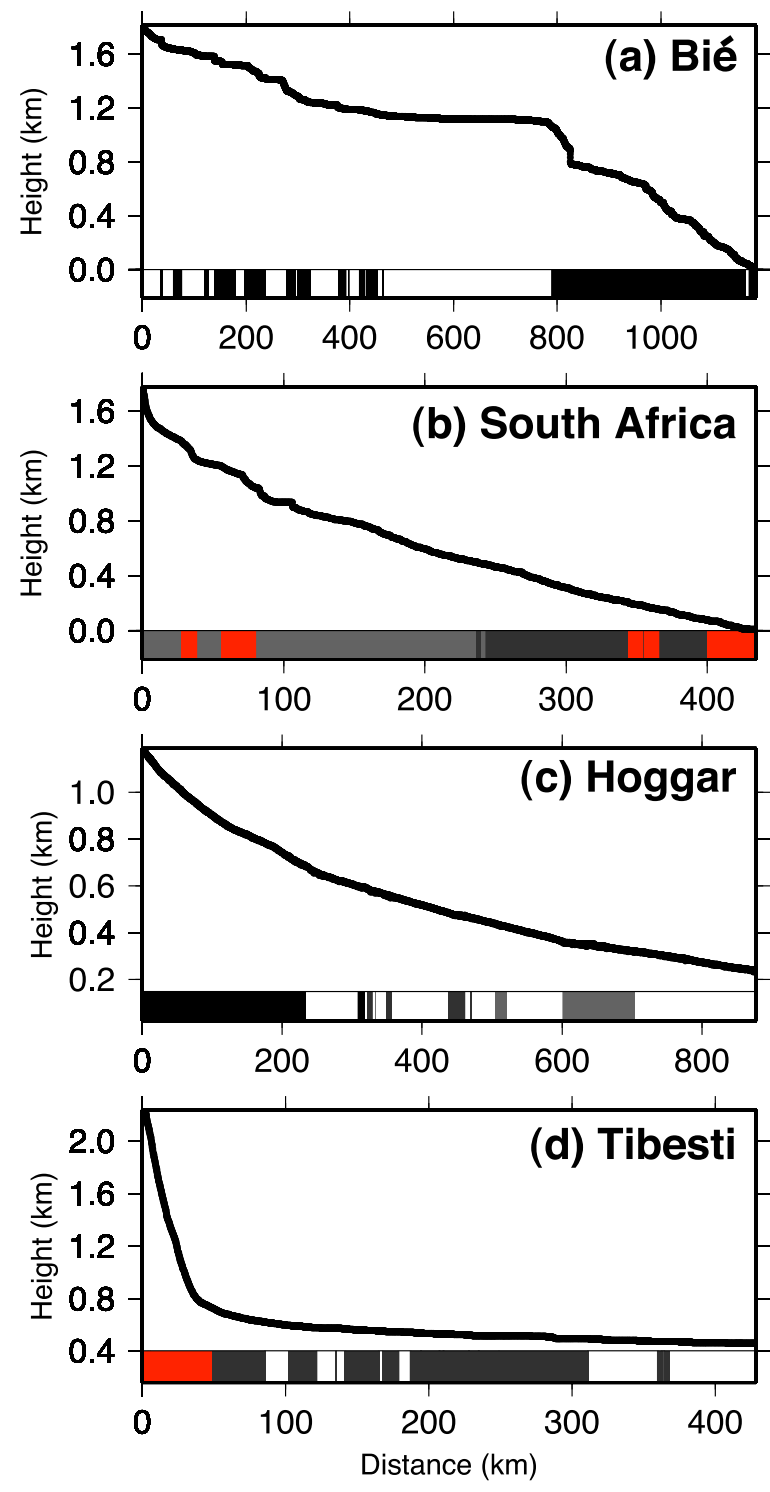

Figure 2. $(a-d)$ Four representative longitudinal river profiles from a database of 74 rivers, which drain topographic swells (see Figure 1). Each river profile was extracted from SRTM topographic data using flow-routing algorithms from ESRI ArcView software. Solid black line represents longitudinal river profile; black, gray, white, and red bars along base of each diagram represent Precambrian basement, Paleozoic/Mesozoic sedimentary rocks, Cenozoic sedimentary rocks, and magmatic rocks, respectively [Choubert and Faure-Muret, 1990]. Bed rock was divided into these four categories based upon presumed erosional resistance.

evolution [Wobus et al., 2006b]. This debate centers upon the relative role of intrinsic and extrinsic controls. The most obvious intrinsic controls are lithologic variation (i.e., rock composition, structural and stratigraphic anisotropy) and changes in channel width. It is often assumed that changes in lithology play a key role in determining, for example, profile slope and localization of knickpoints. However, when we plot lithologic variation along individual river profiles, there is scant evidence for a positive correlation between lithology and slope (Figure 2). Analysis of river profiles from the Bié, South Africa, Hoggar, and Tibesti domes shows that knickpoints and other changes in slope rarely correlate with significant lithologic boundaries (Figure 4). In some instances, correlation is in the opposite sense to that expected. A lack of positive correlation is both surprising and puzzling. One possible explanation is that, regardless of their intrinsic strength, different rock types probably fracture, weather and erode on timescales of $10^{\circ}-$ $10^{6}$ years. On timescales relevant to river profile development, regolithic strength may be more important than lithologic composition. We are reluctant to parameterize lithologic variation and include it in our forward model since the empirical observations summarized in Figures 2 and 4 indicate that there is no compelling reason to do so.

[10] Effects of channel width changes are much discussed [e.g., Turowski et al., 2006; Amos and Burbank, 2007]. The theoretical and experimental response of a river channel, which experiences an increase in incision rate, is channel narrowing and deepening. This change increases bed shear stresses along the channel floor and sides, which enhances the erosion rate [Turowski et al., 2006]. Similarly, if uplift occurs, the channel also adjusts by narrowing and stream power increases until a threshold limit is attained and slope adjustment becomes the dominant equilibrium mechanism. Numerous examples show the expected correlation between increased uplift rate and channel width [Snyder et al., 2000; Lavé and Avouac, 2001; Duvall et al., 2004]. Nevertheless, it is unclear where and when channel constriction actually occurs. On the spatial and temporal scales of interest to us, channel constriction is probably a rapid and transient process (e.g., $10^{3}$ years [Amos and Burbank, 2007]) and we have not explicitly included this effect in our model.

[11] The two most important extrinsic controls are changes in rate of uplift and changes in climate. Uplift rate history is obviously of direct importance and is our primary interest. Climatic changes might be important but it is less obvious how these changes can be satisfactorily parameterized. Two tangible factors are directly controlled by climate: weathering and discharge. Weathering affects integrity of the rock mass and controls regolith formation but, as we have seen, empirical observations suggest that river profile shapes are not primarily governed either by lithology or by degree of weathering (compare river profiles from the Hoggar and Bié domes; Figure 2). Discharge controls stream power but it is probable that the integrated discharge along a river profile over long timescales $\left(\sim 10^{6}\right.$ years $)$ is more relevant than instantaneous discharge. Although it is undoubtedly necessary to exceed a given threshold of discharge before significant channel slope adjustment occurs [e.g., Snyder et al., 2003], mature river channels often occur in arid regions where discharge is highly intermittent. Conversely, immature channels can occur in tropical regions where discharge is less variable. There is little information about discharge as a function of geologic time; present-day (i.e., instantaneous) discharge is probably an unreliable guide. If integrated discharge is important, then a simple parameterization of discharge is probably justifiable. In our forward problem, one such model of discharge is implicit (i.e., $x^{m}$ ) but we readily acknowledge that other models could be used. 

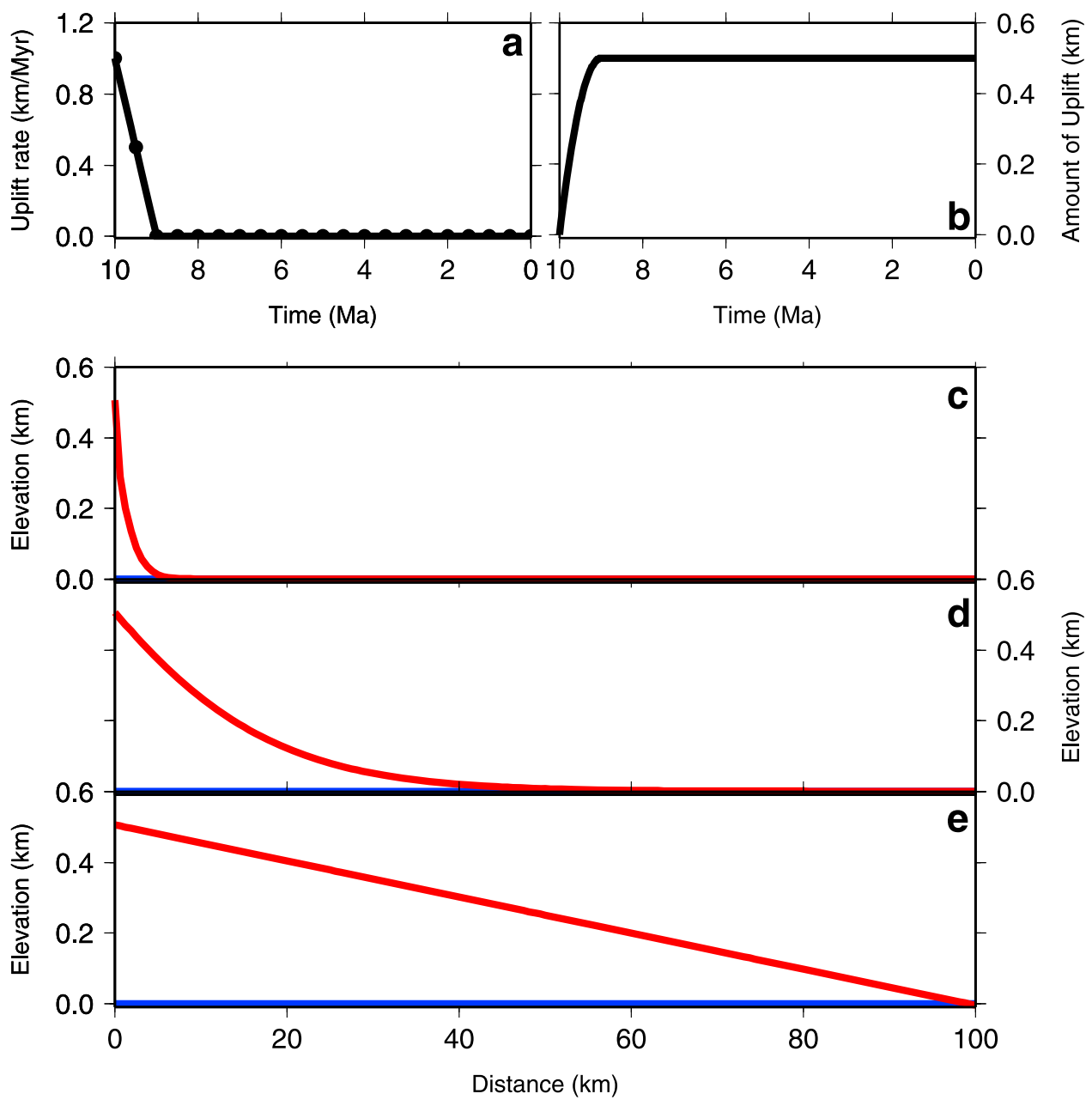

Figure 3. Forward modeling of river profiles. (a) Solid circles and line show discretized uplift rate as a function of geologic time, which was used to calculate river profiles; (b) solid line shows cumulative uplift as function of geologic time (i.e., $\int_{0}^{t} U d t$ ); (c) solid red line is river profile calculated using uplift rate history shown in Figure 3a, where erosive response of river is dominated by knickpoint retreat (i.e., $P e \gg 1)$; (d) erosive response is dominated by a combination of knickpoint retreat and down-wearing (i.e., $P e \sim 1$ ); (e) erosive response is dominated by down-wearing (i.e., $P e \ll 1$ ). See Appendix A for definition of $P e$.

[12] In its general form, equation (1) is not amenable to analytical attack, although dimensional analysis provides general insight (Appendix A). We have solved equation (1) using standard finite difference techniques. To achieve stability and accuracy, we have used an operator splitting technique, which combines the Crank-Nicolson and upwind differencing schemes (see Appendix B for details).

\section{Inverse Problem}

[13] From a geologic perspective, we are primarily interested in solving the inverse problem: what is the smoothest uplift rate history, $U(t)$, which yields the best fit between calculated and observed river profiles? We will first assume that the four erosional constants (i.e., $v, m, n, \kappa)$ are known. During inversion, different distributions of $U(t)$ are used to calculate river profiles which are then compared to the observed river profile. In our starting model, $U(t)=0$ and $z(x)=0$ (i.e., there is no topography). $U(t)$ is systematically varied until calculated and observed river profiles agree within error. To implement this scheme, $U(t)$ is parameterized by selecting $M$ discrete values, $U_{k}$, with a time interval of $\delta t$ where $\delta t$ is typically 1-5 Myrs. The optimal values of $U_{k}$ are interpolated to determine $U(t)$. To stabilize the inversion algorithm, smoothing is imposed upon $U(t)$. Since this problem is nonlinear and since all values of $U$ should be greater than zero, we choose to minimize a trial function, $H$, by varying $U_{k}$ where

$$
\begin{aligned}
H= & {\left[\frac{1}{N} \sum_{i=1}^{N}\left(\frac{z_{i}^{o}-z_{i}^{c}}{\sigma_{i}}\right)^{2}\right]^{\frac{1}{2}}+W_{1}\left[\frac{1}{M-1} \sum_{k=2}^{M}\left(\frac{U_{k}-U_{k-1}}{\delta t}\right)^{2}\right]^{\frac{1}{2}} } \\
& +W_{2}\left[\frac{1}{M} \sum_{k=1}^{M}\left(U_{k}^{\prime \prime}\right)\right]+\frac{W_{3}}{M} \sum_{k=1}^{M} f_{1} .
\end{aligned}
$$

where $z_{i}^{o}$ and $z_{i}^{c}$ are the observed and calculated river elevations, respectively. $N$ is the number of data points. $W_{1}$, 

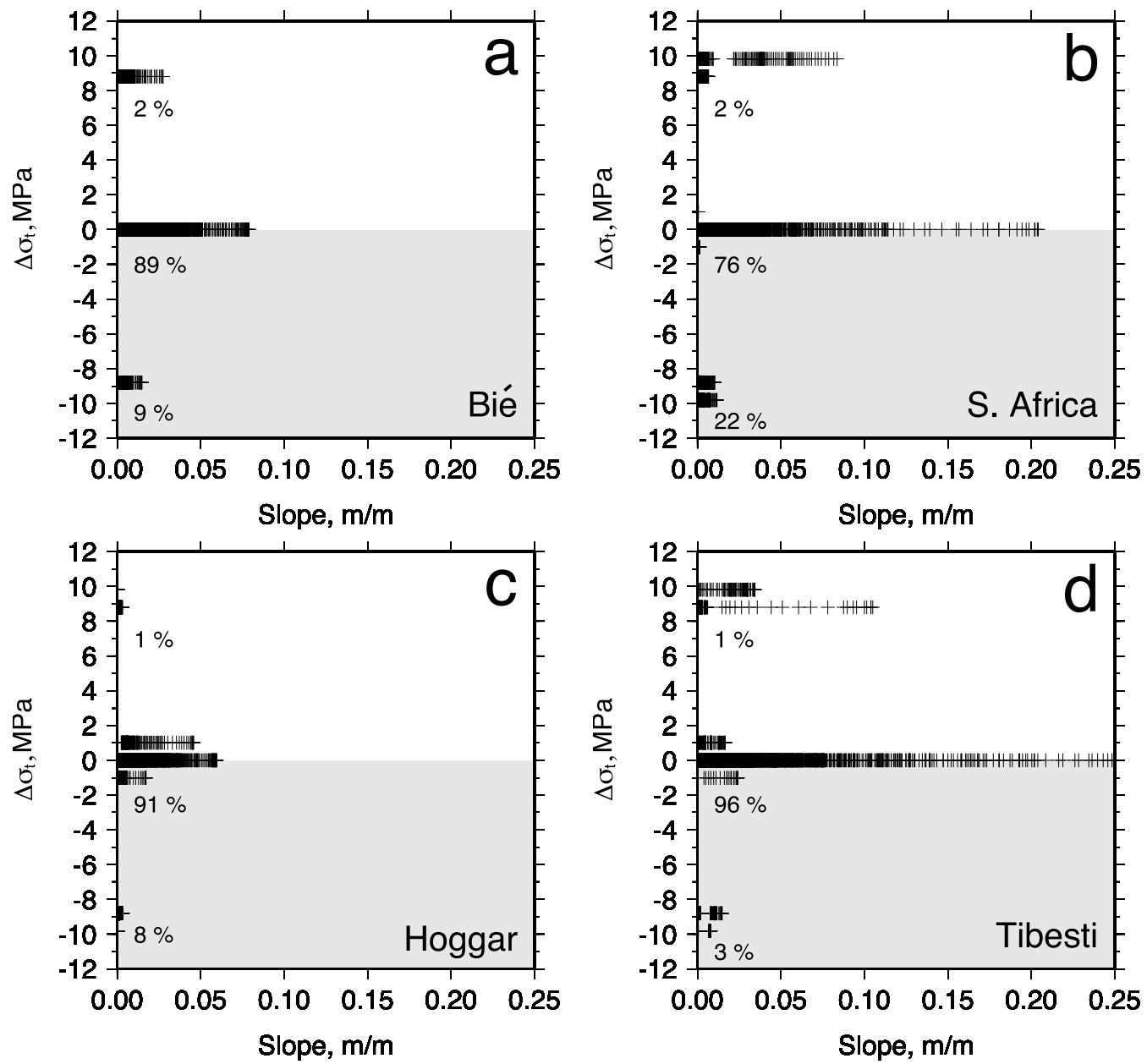

Figure 4. Difference in tensile strength of rocks located along 54 river profiles, $\Delta \sigma_{t}$, plotted as a function of slope for sets of river profiles from African domes. $\sigma_{t}$ is a measure of rock erodibility [Sklar and Dietrich, 2001]. In each case, slope is measured along a river profile. $\Delta \sigma_{t}$ is estimated within a $2 \mathrm{~km}$ moving window and its maximum value is recorded. Crosses represent measurements of tensile strength difference for a given slope; white and gray fields denote positive and negative correlation with slope, respectively. (a) Analysis of 10 rivers draining Bié dome (90,048 measurements); (b) 20 rivers from South Africa dome (177,389 measurements); (c) 12 rivers from Hoggar dome (94,186 measurements); (d) 12 rivers from Tibesti dome (39,980 measurements). Note that the highest slopes do not correlate with large values of $\Delta \sigma_{t}$. There are also numerous locations where slope negatively correlates with $\Delta \sigma_{t}$. Both observations suggest that slope is not primarily controlled either by lithology or by change in lithology.

$W_{2}$, and $W_{3}$ are weighting coefficients. $U^{\prime \prime}{ }_{k}$ are estimates of the second derivative of $U$ generated by cubic spline interpolation. The last term is given by

$$
f_{1}=\left\{\begin{aligned}
\cosh \left(U_{k}\right)-1 & : U<0 \\
0 & : U \geq 0 .
\end{aligned}\right.
$$

The first term on the right-hand side of equation (3) is zero when calculated and observed values of $z_{i}$ agree for an entire river profile. Dividing the difference between them by $\sigma_{i}$, the variance, ensures that each term in the summation has unit variance. The second and third terms cause $U(t)$ to be smooth, and the fourth term is a positivity constraint. The results discussed below were obtained using $W_{1}=0.01, W_{2}=$ 0.01 and $W_{3}=0.001$. Changing these weighting coefficients, even by several orders of magnitude, does not significantly affect our conclusions. A conjugate gradient search method is used to minimize $H$ [Press et al., 1992].

[14] This algorithm has been applied to synthetic data generated by forward modeling, which enables us to assess the robustness of the inverse calculation (Figure 5). For perfect data, calculated distributions of $U(t)$ match forwardmodeled inputs. Progressively discretized data with added random noise have also been inverted and demonstrate that stable results can be obtained, although the algorithm's ability to recover the amplitude and phase of high-frequency uplift rate variations progressively deteriorates.

[15] When an acceptable solution is found, it is important to examine the tradeoff between, and resolution of, model parameters. The first step is to check how the misfit function 


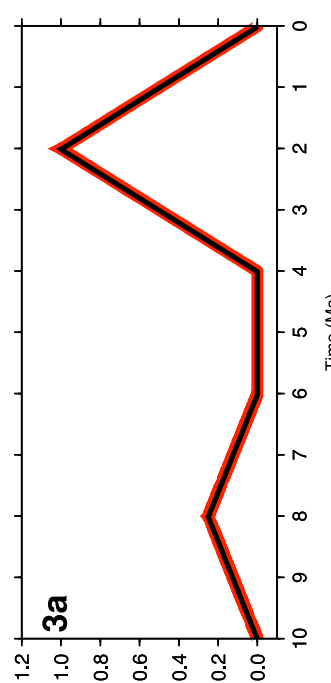

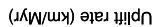

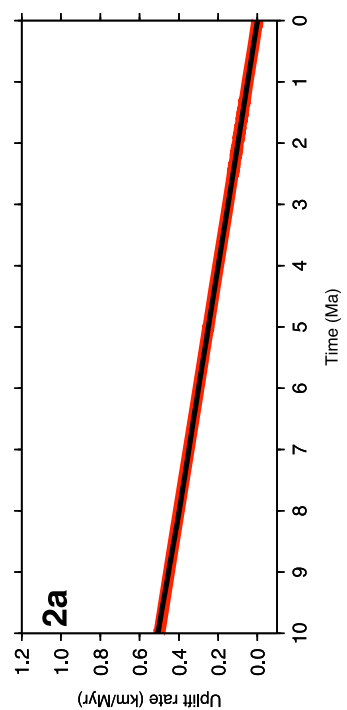

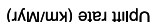
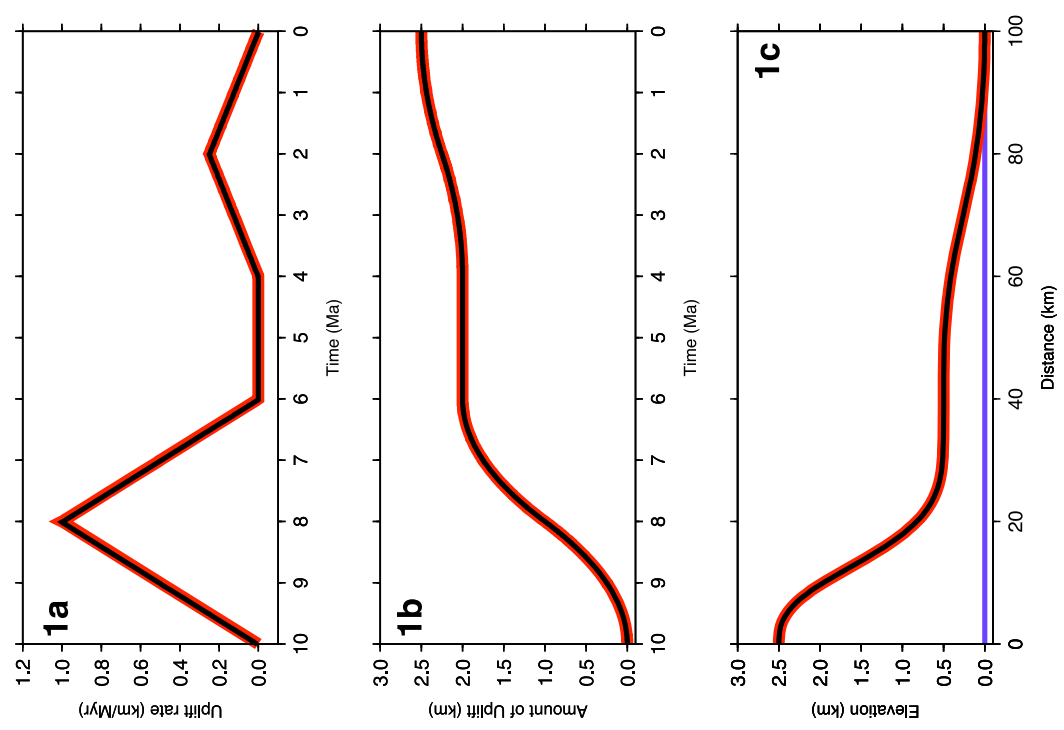
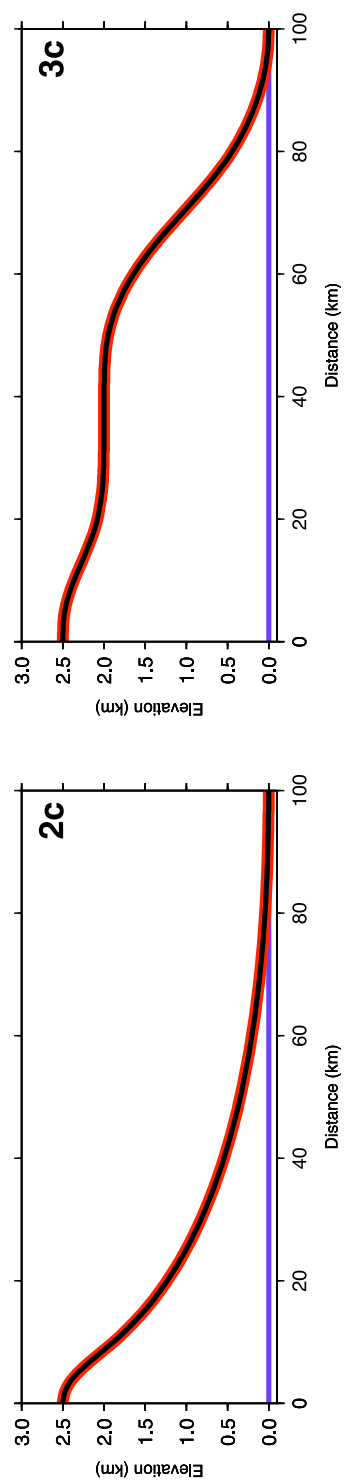

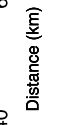

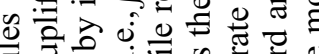

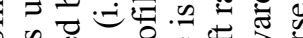

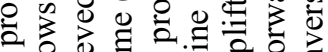

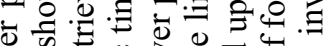

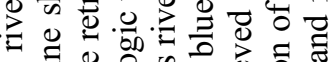

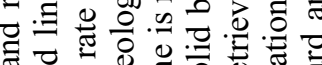

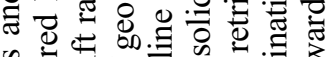

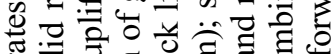

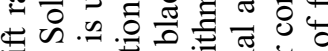

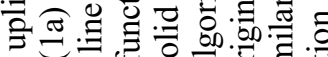

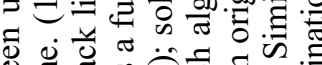
षे

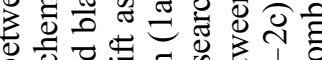
D

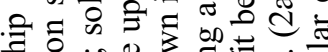
के

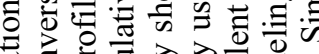

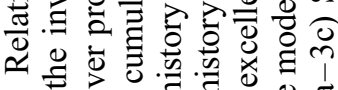
.

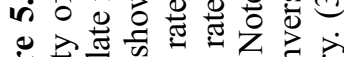

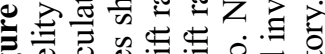

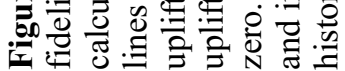


varies with $v, m, n$, and $\kappa$. Figure 6 shows misfit functions for two synthetic river profiles (youthful and mature). In each case, uplift rate history is kept fixed and the misfit function is calculated by varying $v, m, n$, and $\kappa$. Here $\kappa$ is usually poorly constrained which suggests that transportlimited erosion plays a minor role in river profile development, contra Rosenbloom and Anderson [1994]. However, there is a significant effect on misfit when $\kappa>10^{7}$ (i.e., $P e \ll 1$, Appendix A). Here $v$ is also not very well constrained and in fact its purpose is to ensure that the advective term is dimensionally correct. Nonetheless, misfit does vary with $v$ and it is important to include $v$ in the inversion algorithm. The variation of misfit as a function of the exponents $m$ and $n$ is of interest. Here $m$ is always tightly constrained; there is negative tradeoff with $v$ as expected but this tradeoff only becomes really significant when $v$ is very small. Here $n$ is, to some extent, weakly determined and trades off positively against both $v$ and $m$ [Tomkin et al., 2003]. Thus $m$ is the best constrained parameter. For youthful river profiles, $m$ has a weak lower bound because $m$ dominates the advective term and displaces a knickpoint further upstream at any given time. If $m$ is too large, the advective velocity is too high and immature profiles cannot be adequately fitted. If $m$ is too small, the advective velocity is low but immature profiles can still be fitted reasonably well, yielding a low misfit. For mature river profiles, $m$ has a weak upper bound because large values of $m$ can more easily generate mature river profiles.

[16] How robust are the recovered values of $U(t)$ ? For the inverse calculations shown in Figure 5, we have chosen values of the erosional constants, which yield reasonable knickpoint retreat velocities (i.e., $v=50 \mathrm{~m}^{(1-m)} \mathrm{Myr}^{-1}, m=$ $0.5, n=1$, and $\kappa=5 \times 10^{4} \mathrm{~m}^{2} \mathrm{Myr}^{-1}$ [Crosby and Whipple, 2006]. Here $n$ could be greater than 1 but it is unlikely to be very large since there is no clear evidence that knickpoint retreat exhibits shock-wave behavior. Note that our value of $m$ is smaller than published values. How do changes in $v, m$, $n$, and $\kappa$ affect recovered distributions of $U(t)$ ? Monte Carlo simulation is a robust way of mapping parameter uncertainties into model uncertainties. Each river profile has been inverted 50 different times. At the start of each run, $v, m, n$, and $\kappa$ were randomly assigned values from bounded ranges. At the end of each run, the resultant uplift rate history was deemed acceptable provided that the fit between the calculated and observed river profiles was good. In this way, uncertainties in the four erosional parameters are mapped into uncertainties in the uplift rate histories. An average uplift rate history and its uncertainty was calculated by summing acceptable uplift rate histories. Monte Carlo simulations of synthetic and observed river profiles have produced two significant results (Figure 7). First, the chosen bounds for $v, m, n$, and $\kappa$ must be narrowly defined: otherwise acceptable fits between calculated and observed river profiles cannot be obtained. These bounds are narrower than, but broadly consistent with, published ranges (Table 1). Second, recovered uplift rate histories, $U(t)$, are usually better resolved toward the present-day.

[17] It is important to emphasize that river profiles contain no direct information about the timescale of uplift and that $U(t)$ depends upon values of the four erosional constants. Values of these constants must be carefully chosen, preferably by calibration in regions where there is geologic information about uplift. Independent estimates of cumulative uplift histories often exist [e.g., Burke and Gunnell, 2008]. Optimal values of erosional parameters are obtained by trial and error, the main criteria being goodness of fit and fidelity of calculated uplift history.

\section{Africa}

[18] We have picked five sets of African river profiles to test and calibrate our inversion algorithm. Of all the continents, Africa most clearly illustrates the relationship between convective circulation and dynamic topography [Burke, 1996; Burke and Gunnell, 2008; Al-Hajri et al., 2010]. There are two reasons for this manifestation. First, Africa is mostly surrounded by passive extensional margins and complications associated with orogenic changes in surface elevation are largely absent. Second, the African plate is probably stationary with respect to the underlying circulation, which helps to simplify the topographic expression of convective circulation [Hartley et al., 1996]. Nyblade and Robinson [1994] have shown that a large region, which encompasses subequatorial Africa and includes the surrounding oceanic floor, is anomalously elevated by $\sim 500 \mathrm{~m}$. Beneath this region, seismic tomographic imaging indicates that there is a low velocity anomaly centered at $25^{\circ} \mathrm{S}, 25^{\circ} \mathrm{W}$ and located in the lower mantle [Ritsema et al., 1999]. This anomaly is probably caused by a gigantic thermochemical plume.

[19] Topographic swells of various shapes and sizes dominate the African landscape and it is thought that these features are convectively supported. Long-wavelength $(500-1000 \mathrm{~km})$ free-air gravity anomalies, which are indirectly generated by density variations in the upper mantle, and the results of higher mode surface wave tomography help to gauge the amplitude and wavelength of convectively supported topography (Figure 1) [Al-Hajri et al., 2010]. In North Africa, the Hoggar and Tibesti magmatic swells are elevated by $\sim 0.5-1 \mathrm{~km}$. Within the region defined by Nyblade and Robinson's [1994] superswell, large amagmatic domes occur (e.g. Bié, Namibian, South African). Free-air gravity anomalies, low velocity seismic anomalies, and inferred dynamic topography are corroborated by the unusual physiography and hypsometry of subequatorial Africa [Burke, 1996].

[20] The ages of these different swells are debated and their uplift rate histories are not accurately known. A simultaneous outbreak of volcanic activity throughout the African Plate at $\sim 30 \mathrm{Ma}$, together with increased sedimentation rates within offshore deltas and the reconstructed elevation of a Late Cretaceous surface suggest that the modern African landscape was largely sculpted during the Neogene period [Sahagian, 1988; Burke, 1996; Leturmy et al., 2003; Walford et al., 2005]. Therefore our assumption that $z(x)=0$ (i.e., no topography) before Neogene times is reasonable. Drainage networks of these swells are typically radial but river profile shapes differ considerably from swell to swell (e.g., Figure 2). Here, we use the inverse algorithm to model river profiles from five swells. Our aim is twofold. First, we want to determine how well a wide variety of river 

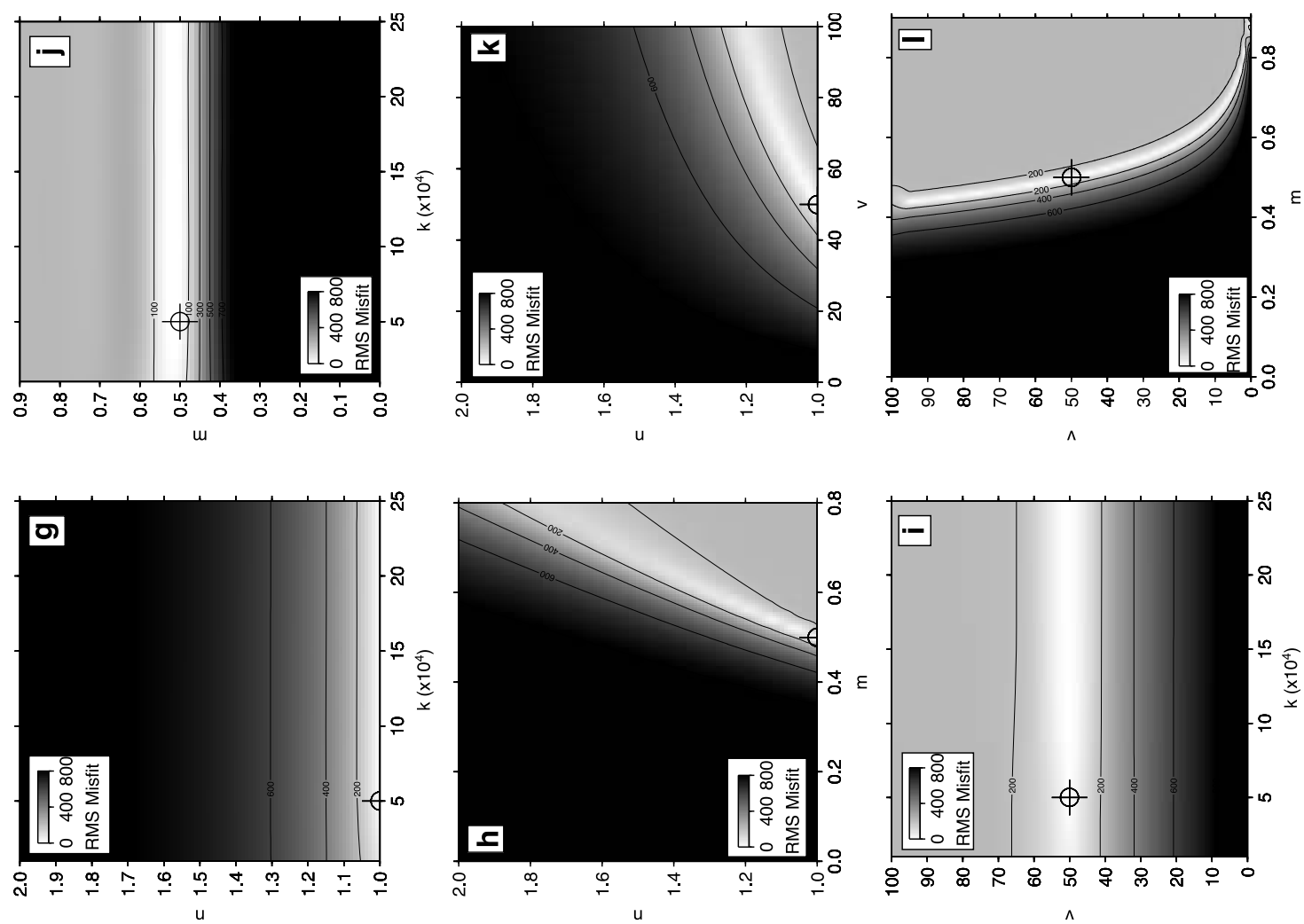

边 票密苛

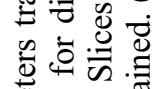
语 递完 可焉的

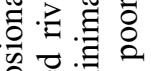

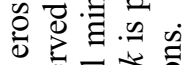

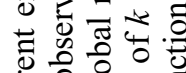

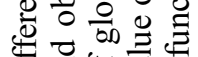

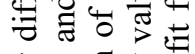

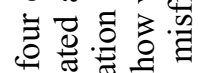

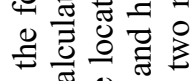
วิ

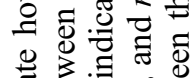

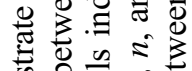
至 0

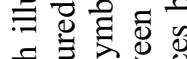
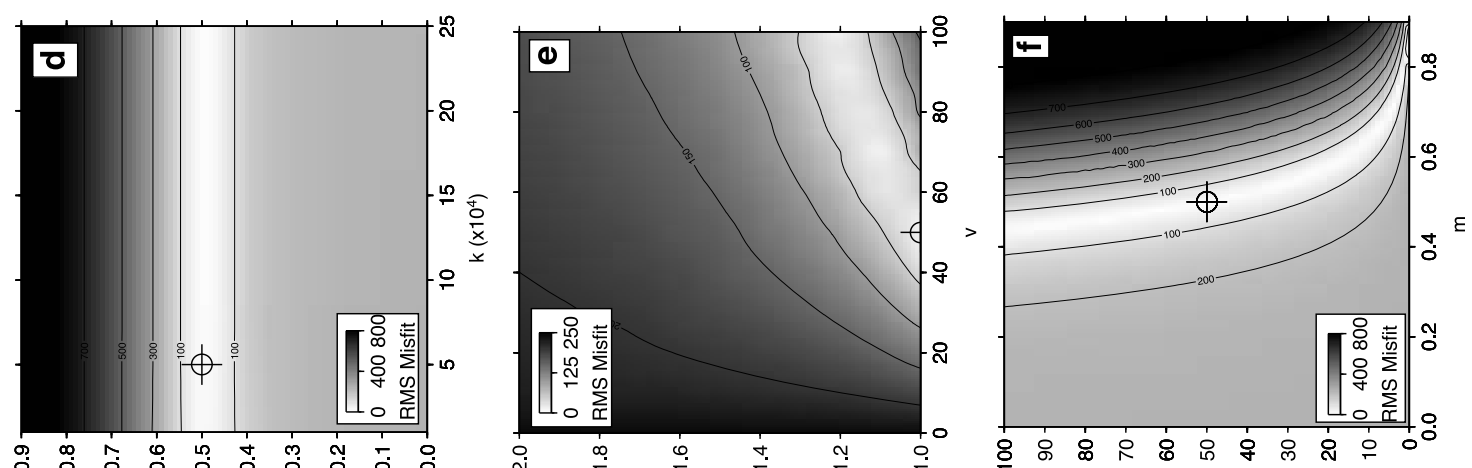

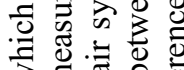
3 矛离

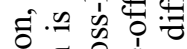

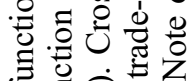
导的吉

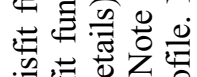

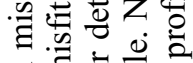

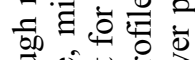

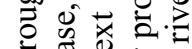

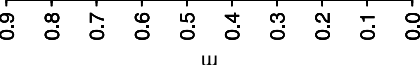
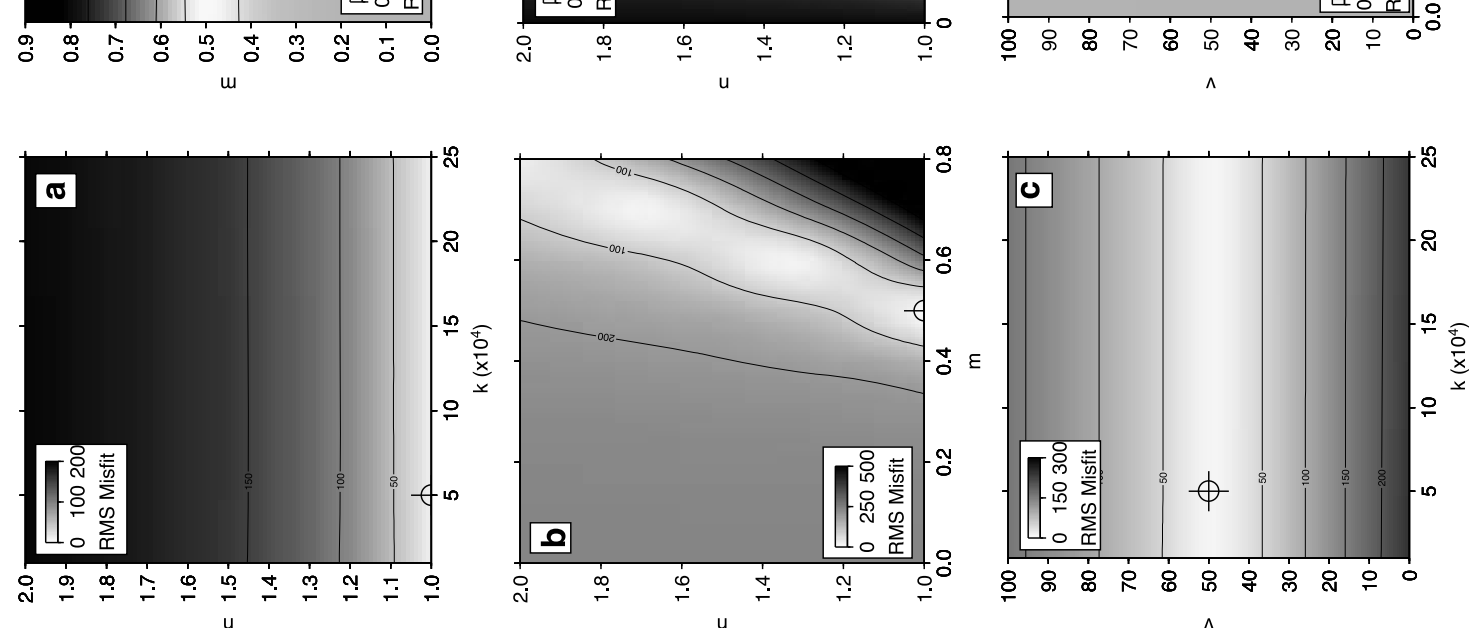
의 웡

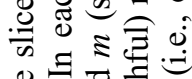

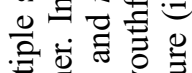

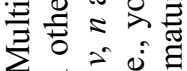
过 ○

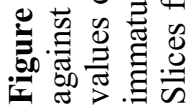



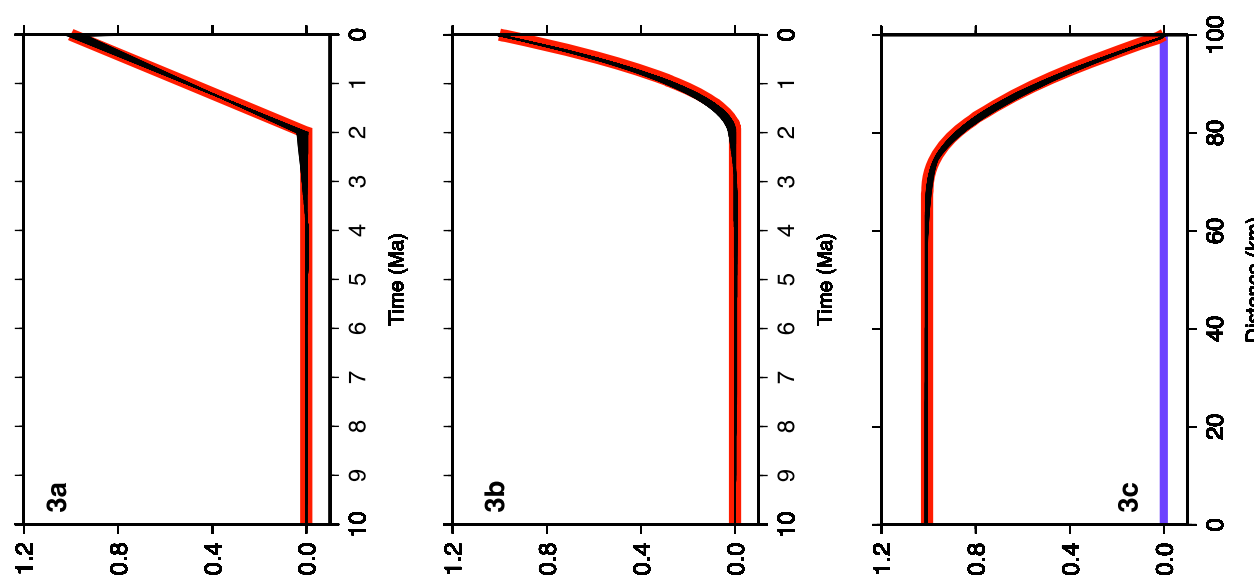

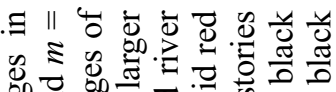

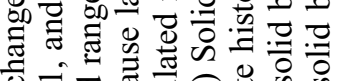
-

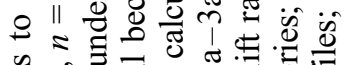

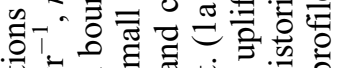

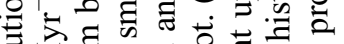

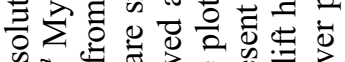

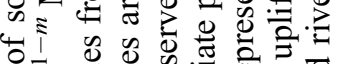

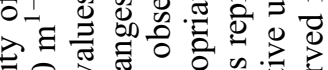

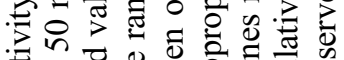
ज苟 焉入.

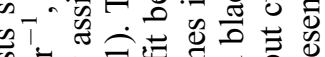
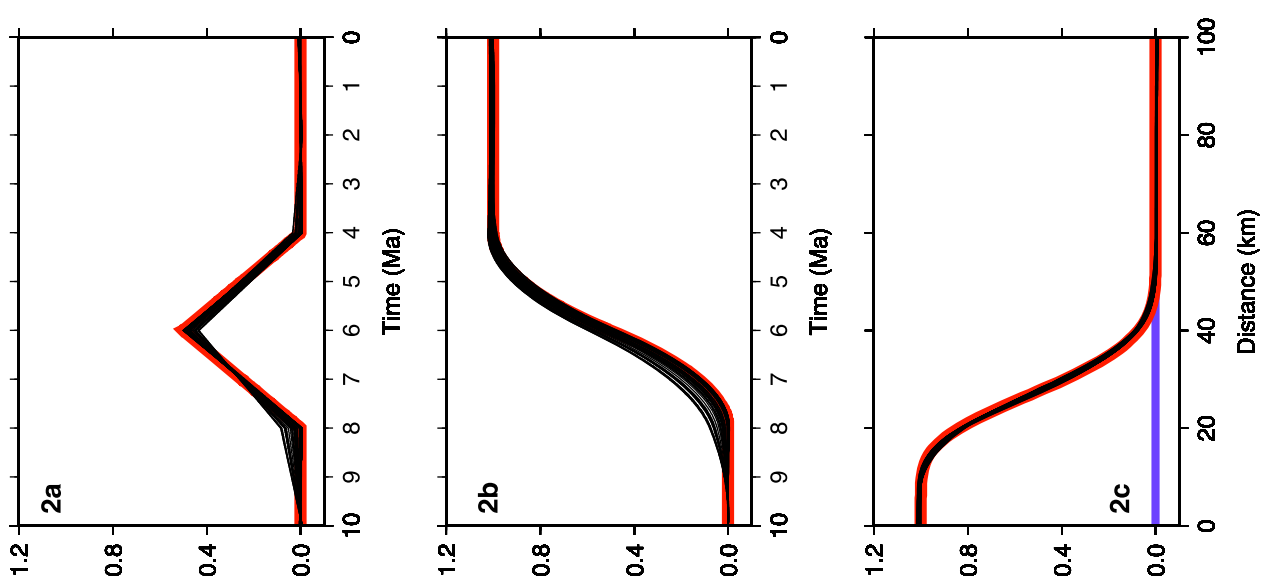

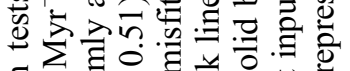
员

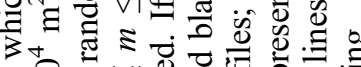

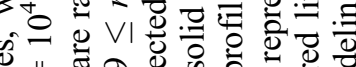

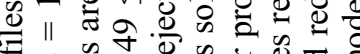
ए

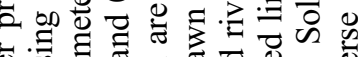

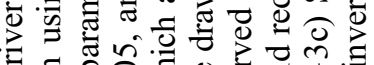

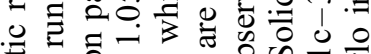
ए.

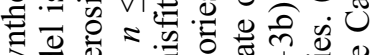

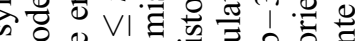

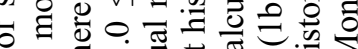

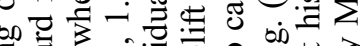

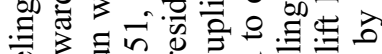
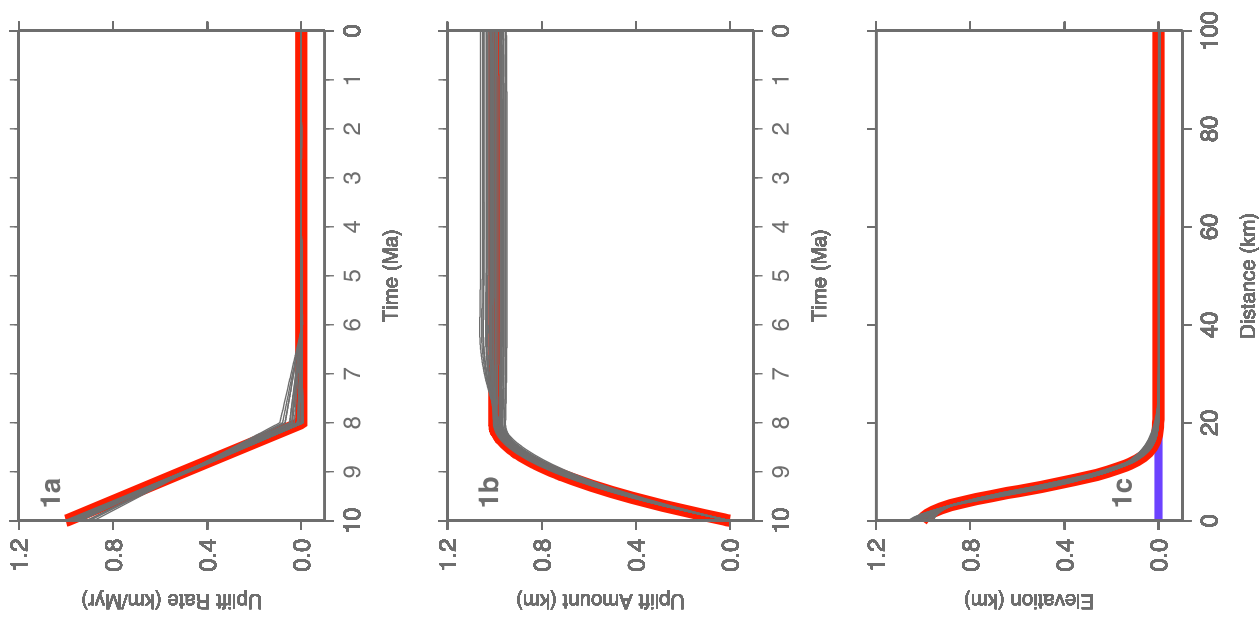

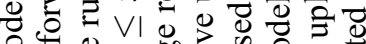
is

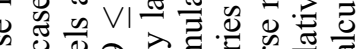
㐘

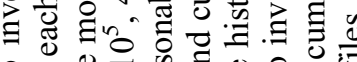
은

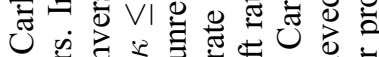

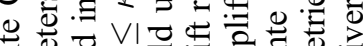

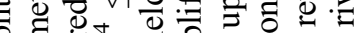

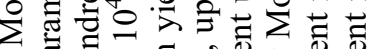

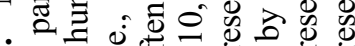
$\therefore$ 西过

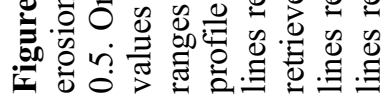


Table 1. Units and Range of Parameter Values Used in This Study

\begin{tabular}{cllr}
\hline Symbol & \multicolumn{1}{c}{ Parameter } & \multicolumn{1}{c}{ Value } & \multicolumn{1}{c}{ Units } \\
\hline$\kappa$ & Diffusive coefficient of erosion & $10^{5}-10^{6}$ & $\mathrm{~m}^{2} \mathrm{Myr}^{-1}$ \\
$v$ & Advective coefficient of erosion & $0.0125-60$ & $\mathrm{~m}^{(1-m)} \mathrm{Myr}^{-1}$ \\
$n$ & Slope exponent & $1.0-1.1$ & dimensionless \\
$m$ & Distance exponent & $0.4-1.2$ & dimensionless \\
$t$ & Time & & $\mathrm{Myr}$ \\
$x$ & Distance along river & $\mathrm{m}$ \\
$z$ & Elevation of river & & $\mathrm{m}$ \\
$U$ & Uplift rate & $10^{5}-10^{6}$ & $\mathrm{~m} \mathrm{Myr}$ \\
$E$ & Erosion rate & 8000 & $\mathrm{myr}$ \\
$L$ & Distance scale & $\mathrm{m}$ \\
$H$ & Elevation scale & & $\mathrm{m}$ \\
\hline
\end{tabular}

profiles can be fitted. Second, we want to predict uplift rate histories and compare our results with published estimates.

[21] For each swell, a digital elevation model was created using the Shuttle Radar Topographic Mission (SRTM) data set [Farr et al., 2007]. We ensured that this model was hydrologically sound by removing anomalous spikes and sinks. A drainage network was extracted using a standard flow-routing algorithm, which identifies the direction of steepest decent (i.e., flow direction) from each cell in the digital elevation model. The number of cells upstream of any given cell is calculated and a threshold drainage area determines the minimum number of cells, which contribute to the initiation of overland flow. The calculated position of a river source is checked using satellite data. SRTM data have cell sizes of $90 \times 90 \mathrm{~m}$, which have been benchmarked against GPS measurements on spatial scales of $10^{1}-10^{6} \mathrm{~m}$. These tests suggest that the vertical and horizontal accuracy of each cell is $\pm 16 \mathrm{~m}$ and $\pm 20 \mathrm{~m}$, respectively [Hancock et al., 2006; Farr et al., 2007]. We have checked the accuracy of planform drainage using satellite imagery which indicates that maximum discrepancy is $<500 \mathrm{~m}$. The vertical resolution of the extracted longitudinal river profiles was checked in a separate study of the Chania region in Crete, where mean vertical discrepancies are $\pm 30 \mathrm{~m}$ (B. Shaw, personal communication, 2009). Vertical resolution decreases to several hundred meters for narrow $(<90 \mathrm{~m})$, deep channels.

[22] We have avoided modeling river profiles where analysis of the digital elevation model indicated drainage reorganization (e.g. river capture, channel switching, backflow along preexisting drainage networks). We have also concentrated on modeling short river profiles which drain to nearby coastlines. There are compelling reasons for these restrictions. First, it ensures that the reference level (i.e. sea level) is known. Rivers which drain internally may have a changing reference level which complicates matters. For example, the southeastern edge of the Bié dome drains into the Okavango delta, which is $\sim 1 \mathrm{~km}$ above sea level. Miller et al. [2005] show that the long-period variation in sea level during Neogene times is less than $100 \mathrm{~m}$. This variation is one order of magnitude less than inferred amounts of cumulative uplift [Burke and Gunnell, 2008]. We have not included sea level variation in our model. Second, long river profiles often cross different swells and depressions and ought to be modeled by allowing uplift rate histories to vary as a function of time and space.
[23] It is important to consider how river discharge could be affected by changes in climate. Although the reconstruction of the Cretaceous-Cenozoic paleoclimate of Africa is fraught with uncertainty, much of the African continent appears to have been eroded to a height of less than $500 \mathrm{~m}$ by Late Cretaceous-Paleocene times. Extensive laterite and bauxite horizons developed, especially in West Africa, which suggest that intense weathering of a low lying continent under a humid and tropic setting. During Early Oligocene times, the climate changed. Until $\sim 2.8 \mathrm{Ma}$, the southern part of Africa was arid. The northern and southeastern coasts of Africa were probably wetter. A region encompassing the Hoggar and Tibesti domes was subjected to seasonal rainfall. Establishment of the Sahara Desert at $2.8 \mathrm{Ma}$ is manifest by an abrupt increase in the proportion of dust-borne sediment in deep-sea cores. The Hoggar and Tibesti domes were drier during this period [Partridge and Maud, 1987; Burke, 1996; de Wit, 1999; Miller et al., 2005; Burke and Gunnell, 2008]. Today, these domes have a rainfall of $\sim 50 \mathrm{~mm} \mathrm{a}^{-1}$. The Bié Plateau is much wetter $\left(>1200 \mathrm{~mm} \mathrm{a}^{-1}\right)$ while the Namibia and South Africa domes have intermediate precipitation $\left(>400 \mathrm{~mm} a^{-1}\right.$ and $>800 \mathrm{~mm} \mathrm{a}^{-1}$, respectively [Nicholson, 2000]). Thus instantaneous discharge has varied considerably during Cenozoic times. Integrated discharge is probably more significant but it is difficult to calculate this important quantity with any certainty.

\subsection{Bié Plateau}

[24] The Bié Plateau reaches elevations of $>2500 \mathrm{~m}$, producing some of the steepest, highest, and most sharply defined parts of the Great Escarpment (Figure 8). Jackson et al. [2005] argue it is difficult to ascribe these elevations to anything other than Cenozoic uplift, given the implausibility of preserving topography which dates from the time of continental breakup at $120 \mathrm{Ma}$ and given the lack of comparable uplift further north. Sahagian [1988] estimated the shape of the Cenomanian depositional surface from Cretaceous shoreline deposits and inferred that $2-3 \mathrm{~km}$ of uplift has occurred. Jackson et al. [2005] report $30^{\circ}-40^{\circ} \mathrm{C}$ of sample cooling north of the Malanje Horst $\left(\sim 8^{\circ} \mathrm{S}\right)$ from fission track analysis of Precambrian apatites and they suggest that $1-1.5 \mathrm{~km}$ of exhumation occurred during Neogene times along the Precambrian rim of the Kwanza Basin. If their sample sites had the same paleodepth as the interior mountains prior to Neogene uplift, then these mountains could have been uplifted by $2.5 \mathrm{~km}$. The Bié dome intersects the African coastline where stratal geometries are consistent with uplift and denudation of a deltaic sedimentary succession. Al-Hajri et al. [2010] argue that the dome grew rapidly within the last 5 Myrs since Pliocene foreset strata are truncated against the seabed along the coastal shelf and uplifted within onshore cliff sections. Estimates of uplift determined from seismic stacking velocities confirm that a major phase of uplift $(0.5-1 \mathrm{~km})$ occurred in post-Pliocene times [Leturmy et al., 2003; Lucazeau et al., 2003; Al-Hajri et al., 2010]. Offshore, the solid flux of sediment increases dramatically after $5 \mathrm{Ma}$ [Lucazeau et al., 2003]. Walford et al. [2005] suggest that domal growth triggered a massive Plio-Pleistocene increase 

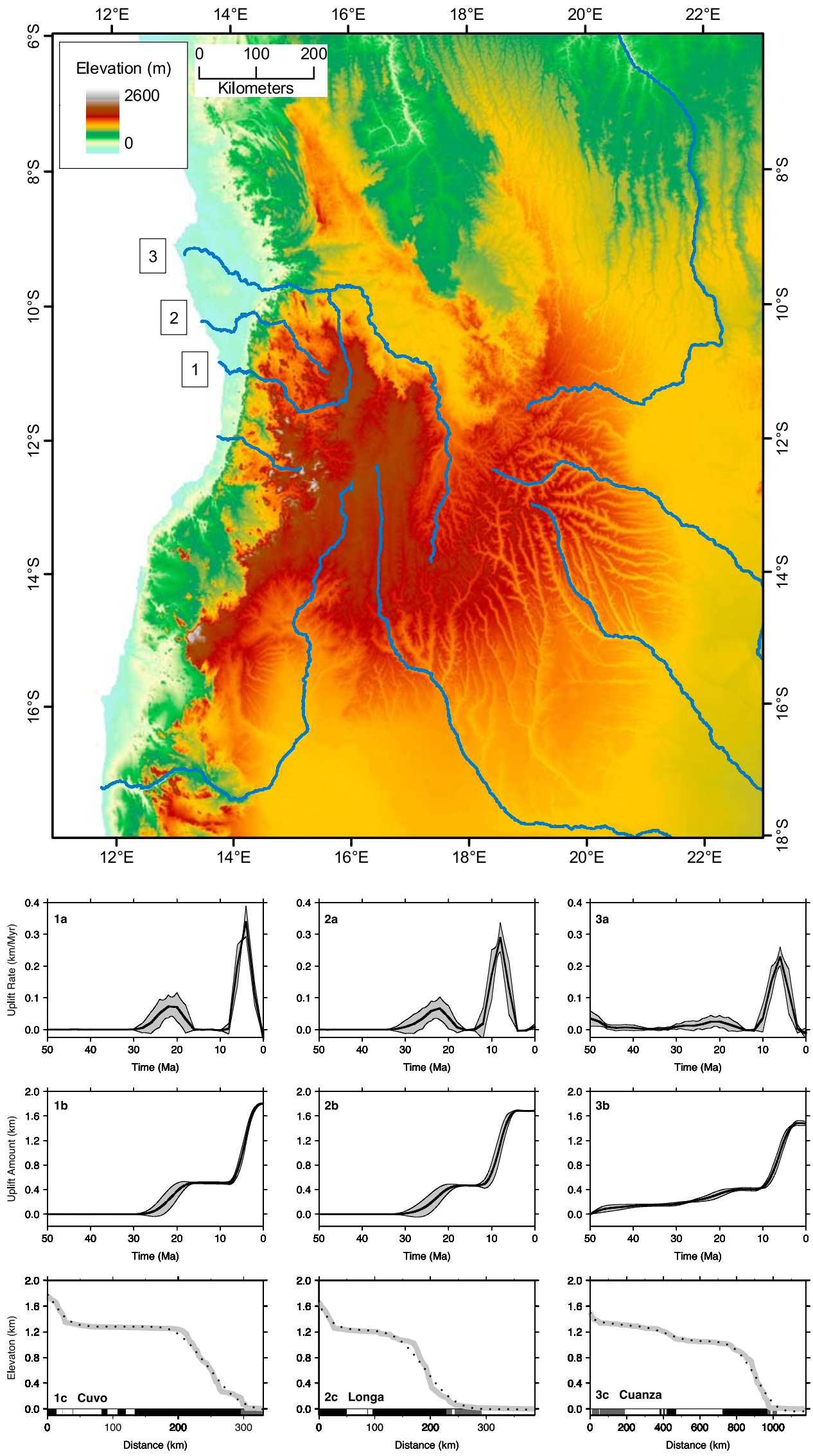

Figure 8 
of solid sedimentary flux into the Congo and Zambezi deltas. This post-Pliocene uplift event is in close agreement with present-day estimates of dynamic topography calculated from the long wavelength gravity anomaly, with the results of higher mode surface wave tomography, and with age-depth residuals of nearby oceanic crust [Al-Hajri et al., 2010; Winterbourne et al., 2010].

[25] Burke [1996] shows that an Oligo-Miocene unconformity can be traced around much of subequatorial Africa. Offshore Angola, the pattern of incision, the inferred magnitude of denudation, and the fact that the OligoMiocene unconformity separates pelagic carbonates from overlying terrigenous siliclastic sedimentary rocks all suggest a link with onshore uplift [Cramez and Jackson, 2000; Jackson et al., 2005]. Stratal geometries and seismic stacking velocities along the West African coastal shelf are consistent with this Middle Oligocene event. Although there is no obvious relationship between the pattern of Oligocene uplift and present-day dynamic topography, an increase in solid sedimentary flux observed in the Congo and Zambezi deltas at 30-35 Ma supports the existence of this earlier phase of uplift.

[26] Leturmy et al. [2003] recognized that river profiles which drain the Bié Plateau are highly immature; they are invariably convex upward with low upstream gradients, which suggests either that uplift has been recent or that profile erosion has been negligible. Dramatic knickpoints observed on these profiles do not coincide with lithologic changes and instead they are more likely to reflect uplift events. We have inverted three river profiles (Figure 8). Excellent fits between observed and calculated river profiles were obtained. The resultant uplift rate histories suggest that a significant phase of uplift $(\sim 0.5 \mathrm{~km})$ occurred within the last 10 Myrs. There is also evidence for a modest $(\sim 200 \mathrm{~m})$ phase of uplift at 20-30 Ma. Uplift rates calculated by inverting the Cuvo river suggests $0.4-0.5 \mathrm{~km}$ of uplift from $\sim 30$ to $18 \mathrm{Ma}$ followed by $1.2-1.4 \mathrm{~km}$ of uplift from 5 to 0 Ma. Modeling of the Longa river indicates that $\sim 0.5 \mathrm{~km}$ of uplift from 30 to $17 \mathrm{Ma}$ was followed by $1.2-1.3 \mathrm{~km}$ of uplift from 12 to $7 \mathrm{Ma}$. Modeling of the Cuanza river requires phases of uplift at 20-30 Ma and at 10-5 Ma. Our results agree with Pliocene and Oligo-Miocene uplift events inferred from onshore and offshore sediment geometry (Figure 13). A late $0.5-1.0 \mathrm{~km}$ increase in uplift amount is consistent with the spatial distribution of dynamic topography predicted from the long-wavelength gravity field if an admittance of $40 \mathrm{mgal} \mathrm{km}^{-1}$ is assumed [Al-Hajri et al., 2010].

\subsection{South African Swell}

[27] Ages of the Drakensberg Escarpment and of the elevated topography of South Africa are hotly debated. Brown et al. [2002] used fission track data to determine the denudational history across the escarpment. They propose an Early Cretaceous episode of accelerated denudation, which is broadly coincident with continental breakup and suggests that $3 \mathrm{~km}$ of denudation occurred between 90 and $70 \mathrm{Ma}$. Critically, Neogene uplift is not invoked to account for the present-day high topography of South Africa. In direct contrast, King [1962], Partridge and Maud [1987], Burke [1996], Partridge [1998], and Burke and Gunnell [2008] all argue that warping of erosional surfaces, elevated Cretaceous shoreline deposits, immature river profiles, and offshore sedimentation are entirely consistent with youthful South African topography. By inference, topographic features formed during continental breakup are assumed to have been rapidly eroded. The present-day elevation of South Africa together with retreat of the Drakensberg Escarpment $(\sim 1000-10,000 \mathrm{~m} / \mathrm{Myr})$ are attributed to $>1 \mathrm{~km}$ of Cenozoic uplift.

[28] Although there are differences in terminology and emphasis, Partridge and Maud [1987] and Burke and Gunnell [2008] agree that South African topography was negligible by Paleogene times. A gentle pediplain with an elevation of $\sim 500 \mathrm{~m}$, referred to as the African Surface, is thought to have extended across the region. During Early Miocene times, $150-300 \mathrm{~m}$ of uplift is inferred from an increase in offshore sedimentation. A second erosional surface then developed, which is usually called the PostAfrican I Surface. Partridge and Maud [1987] suggest that a later erosional cycle produced the Post-African II surface, which developed after a Pliocene phase of uplift. This last phase raised the eastern interior of South Africa by as much as $900 \mathrm{~m}$. The Post-African II erosional cycle is manifest chiefly by deep incision of the coastal hinterland and by down cutting of major rivers. The resulting sedimentation is evident mainly in the offshore deltas of the major rivers. Preservation of discrete erosional surfaces and escarpments attests to the episodic nature of Cenozoic uplift. Finally, Sahagian [1988] estimated the shape of the Cenomanian depositional surface and inferred a post-Cretaceous regional uplift of $2-3 \mathrm{~km}$.

Figure 8. Analysis of Bié Plateau (see Figure 1 for location). This topographic swell intersects west African coastline and has a radial drainage pattern. In main plot, dome topography and selected rivers are shown. Labels indicate river profiles inverted in this study ( 1 indicates Cuvo, 2 indicates Longa, and 3 indicates Cuanza). Each river was inverted 50 times and erosional parameters were assigned random values within bounded ranges of values $\left(2 \times 10^{4} \leq \kappa \leq 7 \times 10^{4}, 49 \leq \mathrm{v} \leq 51\right.$, $1.0 \leq \mathrm{n} \leq 1.05,0.49 \leq \mathrm{m} \leq 0.51)$. These ranges are small because larger ranges often yield unreasonably large residual misfits. This observation implies that erosional constants must be tightly constrained. (1a) Cuvo river profile analysis. Thick black line and gray envelope show mean uplift rate history and its uncertainty which were calculated by Monte Carlo inverse modeling of river profile. Uplift rate histories within envelope yield acceptable fits to river profile (68\% confidence level). (1b) Cumulative uplift history calculated from uplift rate history. At the present day, net cumulative uplift is actually $100 \mathrm{~m}$ smaller because of sea level has fallen during Neogene times [Miller et al., 2005]. (1c) Gray band shows observed river profile, associated uncertainty $\left(\sigma_{i}\right)= \pm 20 \mathrm{~m}$; dotted line shows best fitting theoretical river profiles which was calculated by varying uplift rate history. Bar pattern along $x$ axis shows river bed lithologies (see Figure 2). (2a-2c) Longa river profile analysis. $(3 a-3 c)$ Cuanza river profile analysis. 
[29] In more detail, classic geomorphologic observations show that the Post-African I surface is gently folded, which indicates that Pliocene uplift was concentrated along virtually the same axis as Miocene uplift. On the basis of deformation of earlier surfaces, convex-upward river profiles, and elevation of Early Pliocene marine sedimentary rocks, Partridge and Maud [1987] and Partridge [1998] suggest that uplift along the Ciskei-Swaziland axis varied from $600-900 \mathrm{~m}$, declining to $200 \mathrm{~m}$ in the Oudtshoorn area and to $100 \mathrm{~m}$ or less in the hinterland of the west coast. Concentration of uplift in the eastern part of South Africa greatly accentuated the elevation and tilting imparted by Miocene uplift. A Pliocene uplift event is corroborated by an increase in solid sedimentary flux into the Limpopo delta and into the deeper oceanic basins. A long-wavelength positive free-air gravity anomaly is centered on the region with the highest uplift rates, which suggests that convective circulation beneath the lithospheric plate is responsible for changes in uplift throughout Neogene times.

[30] We have inverted the Camperdown, Umtentu, and Bashee rivers in order to determine their uplift rate histories (Figure 9). These river profiles intersect the southeastern edge of the putative dome. The Camperdown river flows through the region of maximum Cenozoic uplift suggested by Partridge and Maud [1987]. Inversion of this profile indicates that $1.2 \mathrm{~km}$ of uplift occurred in Oligocene to Early Miocene times. A later uplift event with an amplitude $1.2 \mathrm{~km}$ began $10 \mathrm{Ma}$ and continues to the present day. Inversion of the Umtentu river suggests continuous uplift since Late Eocene times, punctuated by a period of slightly slower uplift rate between $20 \mathrm{Ma}$ and $8 \mathrm{Ma}$. Finally, the Bashee river, flowing south of the maximum Cenozoic uplift, suggests that uplift began at $30 \mathrm{Ma}$ and continued to the present day. Thus timing of uplift calculated by inverting South Africa's rivers broadly agrees with independent estimates of uplift. The $\sim 35-20$ Ma stage of increased uplift rate predicted by inverting South Africa's rivers is greater than that suggested by Partridge [1998]. If $0.5-0.6 \mathrm{~km}$ of pre-Cenozoic elevation existed across South Africa, as they suggest, the uplift amount predicted by inverting these three rivers would correlate with their independent constraints (Figure 13).

\subsection{Nambian Swell}

[31] Sahagian [1988] reconstructed a Cenomanian depositional surface which suggests that $2-3 \mathrm{~km}$ of epeirogenic uplift occurred after $\sim 95 \mathrm{Ma}$ in Namibia. Fission track analyses of basement rocks from the Kaoko formation indicates a long-lived cooling history since Early Cretaceous times [Luft et al., 2005]. Thermal modeling of these tracks isolates two periods of cooling: an Eocene-Oligocene (50-30 Ma) event and an accelerated period of cooling in Miocene times ( $25-5 \mathrm{Ma})$. These cooling events correlate with the main stratigraphic discontinuities within the Walvis Basin [Bray et al., 1998; Bray and Lawrence, 1999; Luft et al., 2005]. Luft et al. [2005] interpret the Cenozoic cooling events as indicative of gentle uplift of the continental margin, the age of which can be correlated with increased uplift rate predicted by inverting the Khan, Omaruru, and Ugab rivers of Namibia (Figure 10). Gallagher and Brown's [1999] interpretation of apatite fission track data across
Namibia suggests increased denudation from 70 Ma up to the present, although they note that the most recent $(<20 \mathrm{Ma})$ chronology is suspect due to uncertainties in extrapolating fission track annealing models to low temperatures and long timescales. An increase in denudation from $\sim 50 \mathrm{Ma}$ to the present day is not obviously reflected in offshore sedimentary flux [Gallagher and Brown, 1999]. Nevertheless, offshore basins (e.g., Walvis, Luderitz) do have Cenozoic sedimentary sequences which are up to 1 km thick [Maslanyj et al., 1992; Bray et al., 1998]. Bray and Lawrence [1999] suggest that the lack of proximal accommodation space has triggered deposition of Cenozoic sediments in deeper basinal areas south of the Walvis ridge.

[32] Three rivers drain the Namibian dome to the west coast: the Khan, Omaruru, and Ugab rivers (Figure 10). All three profiles are remarkably linear as a function of distance and inversion suggests that uplift started at $30 \mathrm{Ma}$ and increased linearly with time. The cumulative amount of uplift decreases northward. Maximum cumulative uplift occurs close to the Khan river and the smallest amount occurs adjacent to the Ugab river. Increased northward uplift rate during the last $50 \mathrm{Ma}$ corroborates the spatial variation in the amount of denudation during the Cenozoic inferred from analysis of fission track data [Gallagher and Brown, 1999; Luft et al., 2005]. Inversion of Namibia's rivers corroborates Burke's [1996] suggestion uplift rates increased from $\sim 30 \mathrm{Ma}$ (Figure 13). To what extent are is the linear form of these river profiles controlled by climate? Namibia may have been arid since $34 \mathrm{Ma}$ and there is evidence which suggests that aridity increased at $2.2 \mathrm{Ma}$ [Dupont et al., 2005; Burke and Gunnell, 2008]. Nevertheless, intermittent discharge does occur along the Khan, Omaruru, and Ugab rivers. It is possible that aridity has contributed to the linearity of these profiles but we appeal to the consistency of our results.

\subsection{Hoggar and Tibesti Swells}

[33] The Hoggar and Tibesti domes are characterized by Cenozoic volcanism and both have roughly the same elevation and morphology (Figure 1). These domes are manifest by broad swells, some $1000 \mathrm{~km}$ across, with basement elevations of $300-400 \mathrm{~m}$ on their flanks rising to $1000-1200 \mathrm{~m}$ in the center. Long-wavelength positive free-air gravity anomalies and low-speed surface wave tomographic anomalies are suggestive of low subplate densities. It is generally thought that these domes are supported by anomalously hot asthenosphere which upwells beneath the lithosphere [Lesquer et al., 1989; Wilson and Guiraud, 1992; Al-Hajri et al., 2010].

[34] The uplift histories of the Hoggar and Tibesti massifs are poorly constrained [Wilson and Guiraud, 1992]. During Cenomanian times (100-94 Ma), a Trans-Saharan seaway stretched across much of North Africa; mixed clastic and carbonate facies of Cenomanian age, which is possibly of marine origin, outcrop near the center of the Hoggar dome. Sahagian [1988] has used the distribution of shoreline deposits to calculate a Cenomanian surface which suggests that post-Cenomanian uplift of Hoggar and Tibesti was $2-3 \mathrm{~km}$. Significant Neogene uplift of the Hoggar dome is inferred from the temporal distribution of magmatic activity [Wilson and Guiraud, 1992; Burke, 1996]. Magmatism 

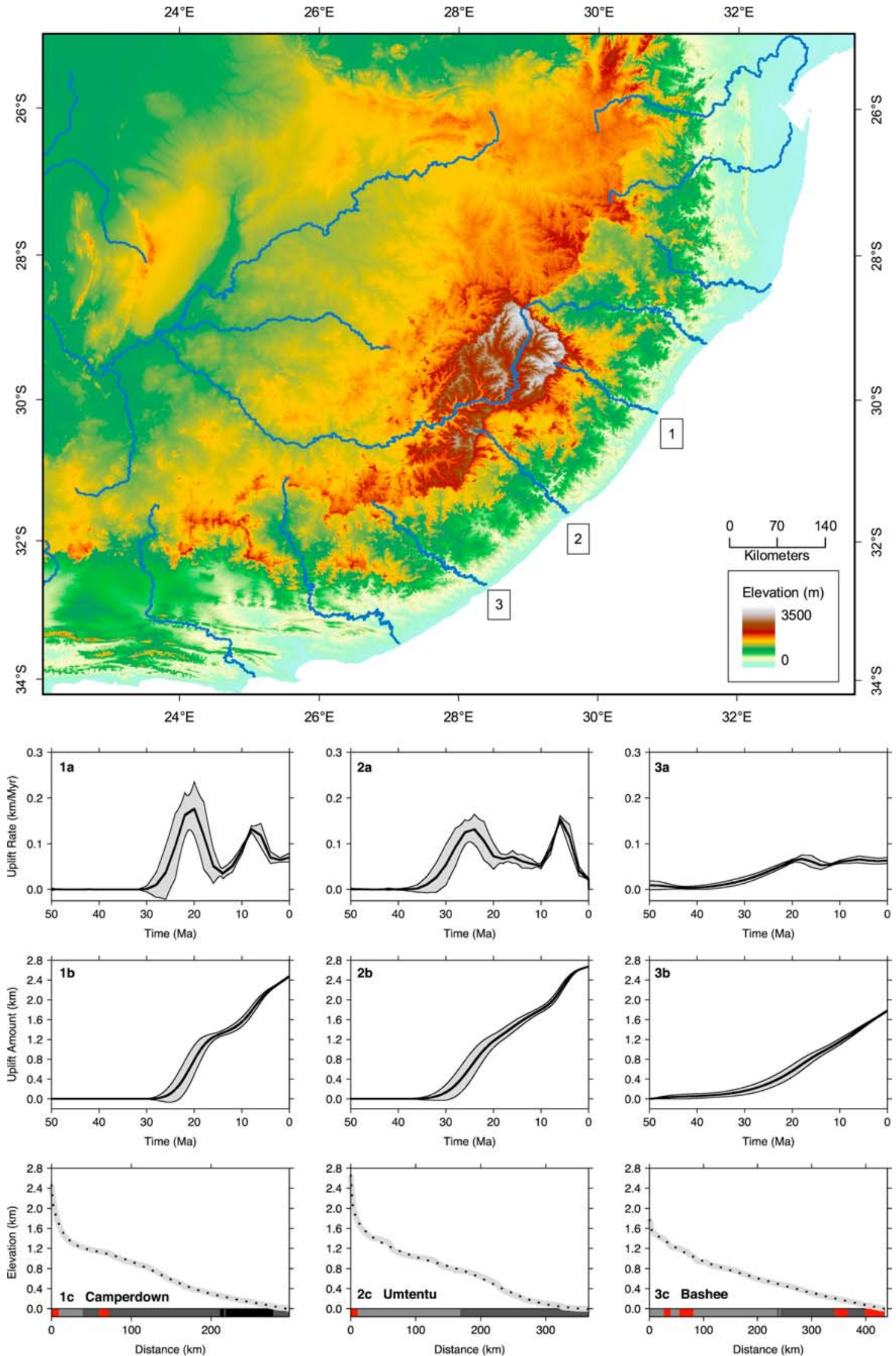

Figure 9. Analysis of South African Dome (see Figure 1 for location). In main plot, dome topography and selected rivers are shown. Labels indicate river profiles inverted in this study (1 indicates Camperdown, 2 indicates Umtentu, and 3 indicates Bashee). See Figure 8 for additional details. 

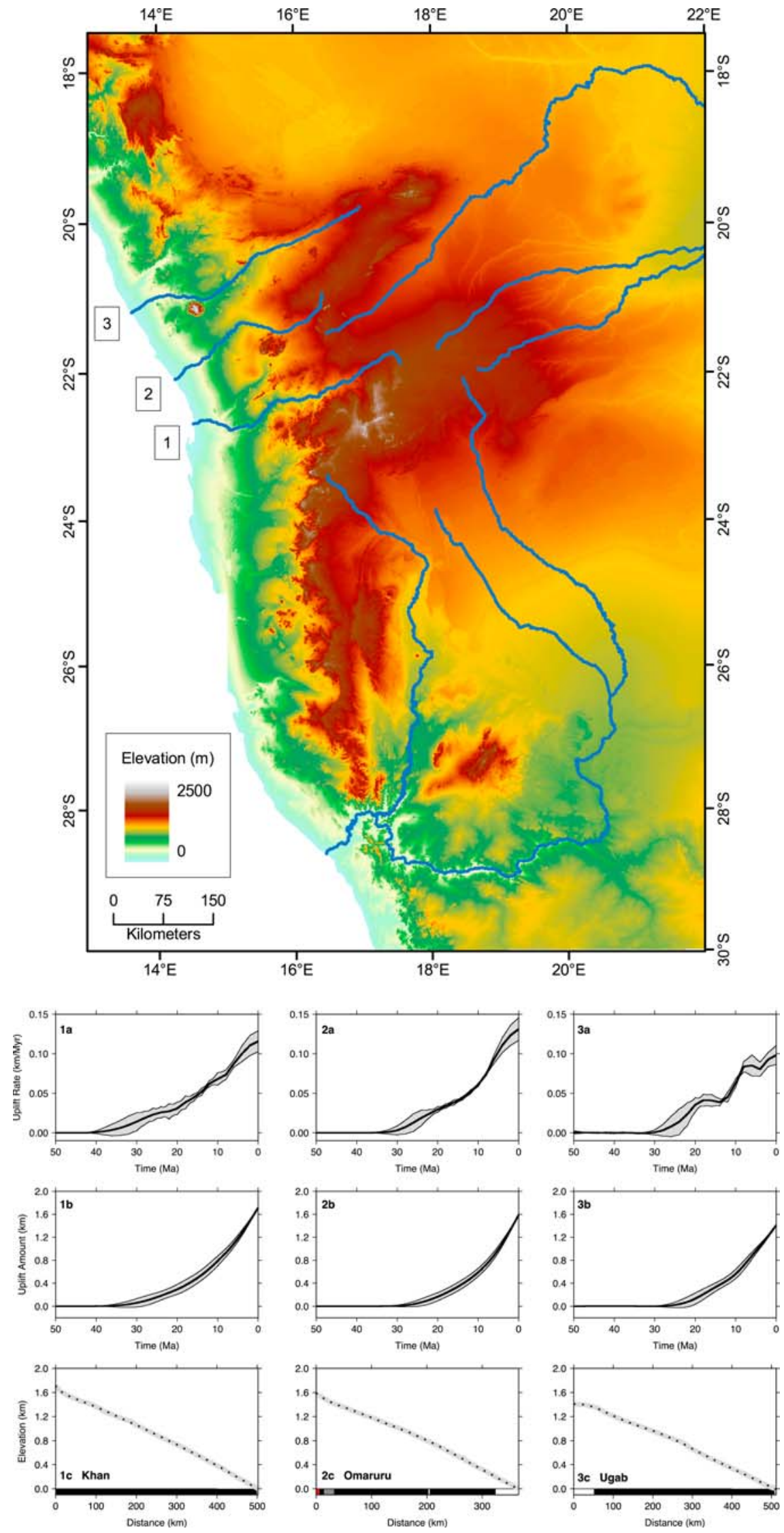

Figure 10. Analysis of Namibian Dome (see Figure 1 for location). In main plot, dome topography and selected rivers are shown. Labels indicate river profiles inverted in this study (1 indicates Khan, 2 indicates Omaruru, and 3 indicates Ugab). See Figure 8 for additional details. 

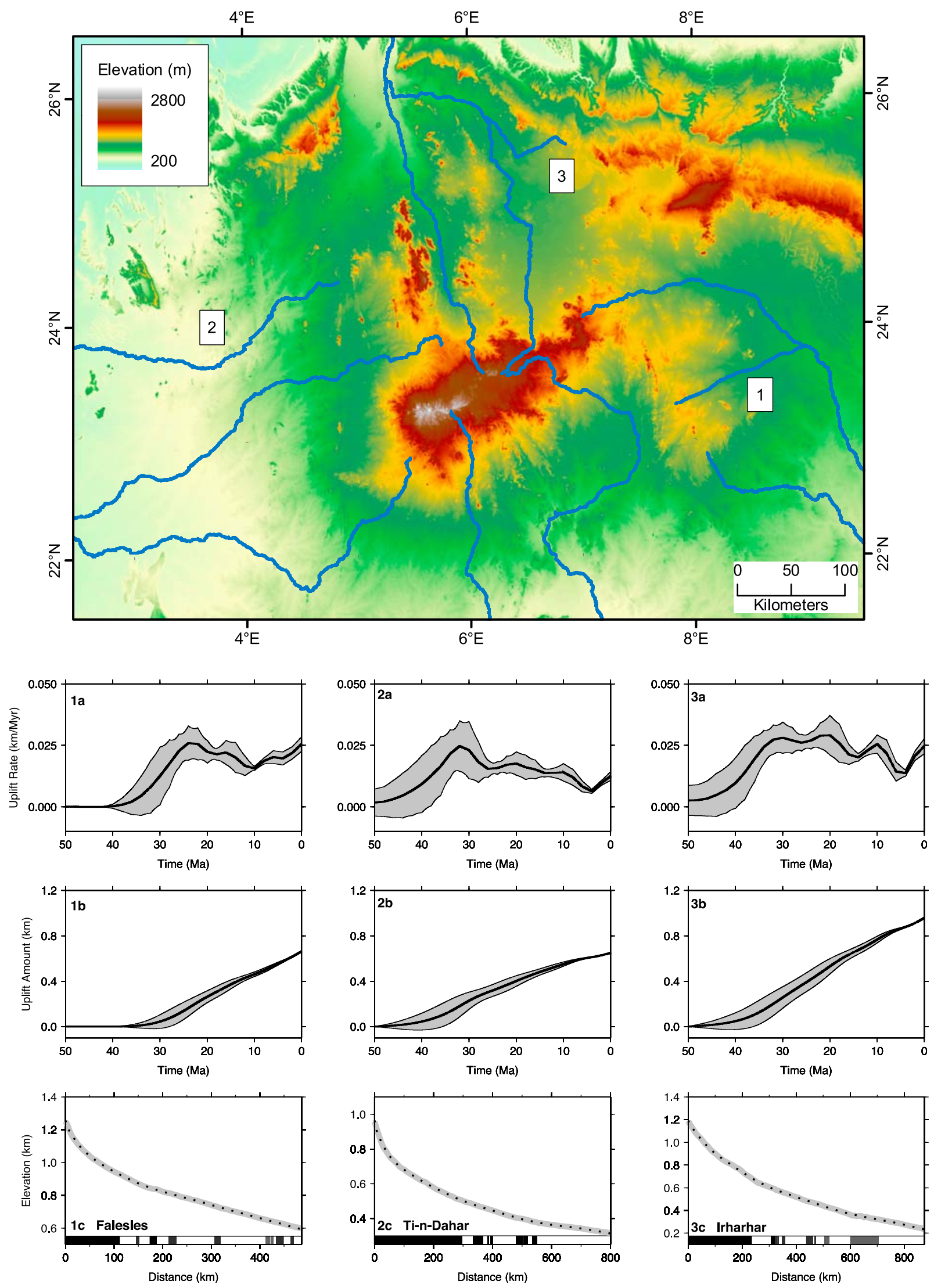

Figure 11. Analysis of Hoggar Dome (see Figure 1 for location). In main plot, dome topography and selected rivers are shown. Labels indicate river profiles inverted in this study (1 indicates Falesles, 2 indicates Ti-n-Dahar, and 3 indicates Irharhar). See Figure 8 for additional details. 

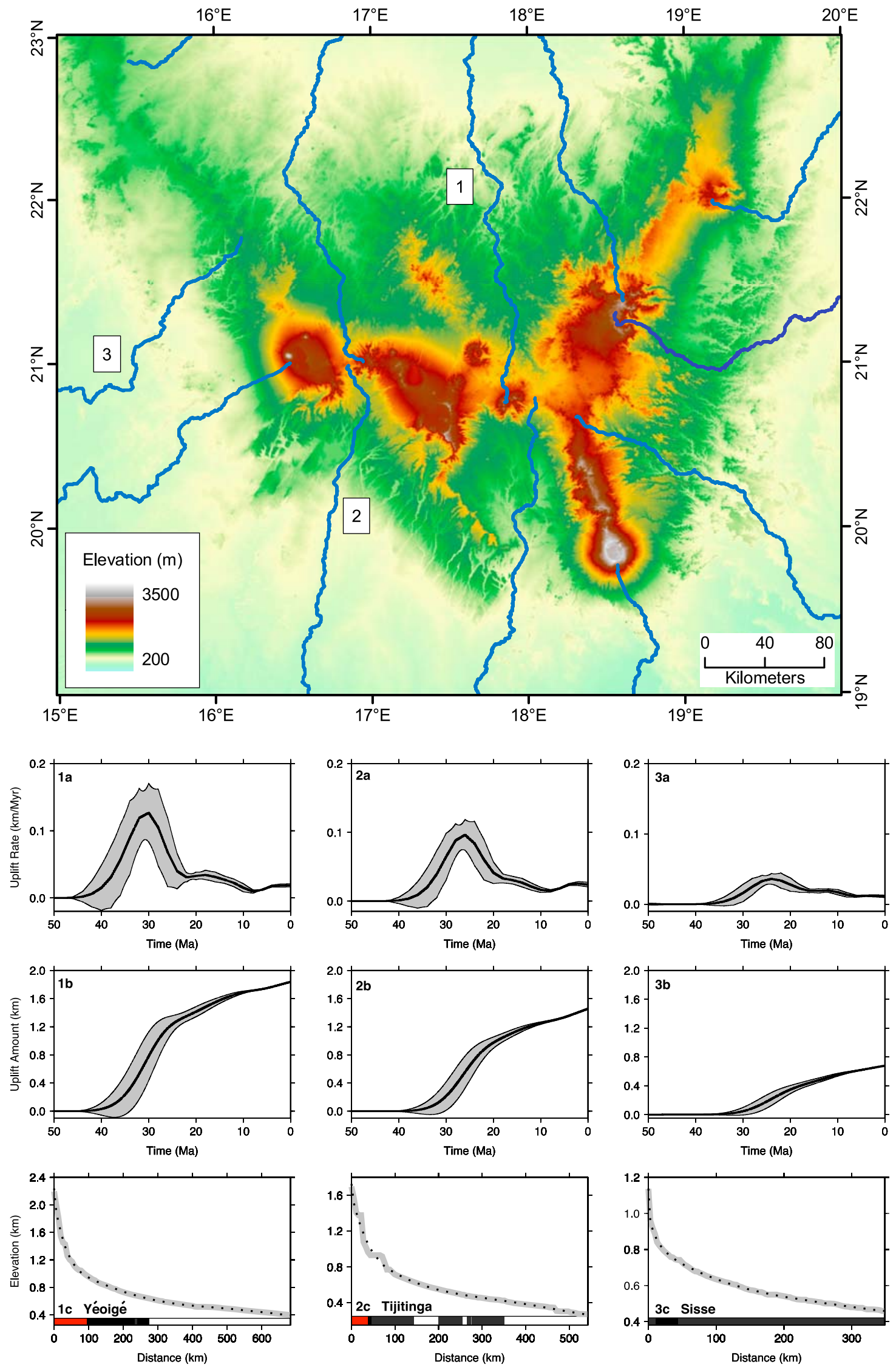

Figure 12. Analysis of Tibesti Dome (see Figure 1 for location). In main plot, dome topography and selected rivers are shown. Labels indicate river profiles inverted in this study (1 indicates Yéoigé, 2 indicates Tijitinga, and 3 indicates Sisse). See Figure 8 for additional details. 

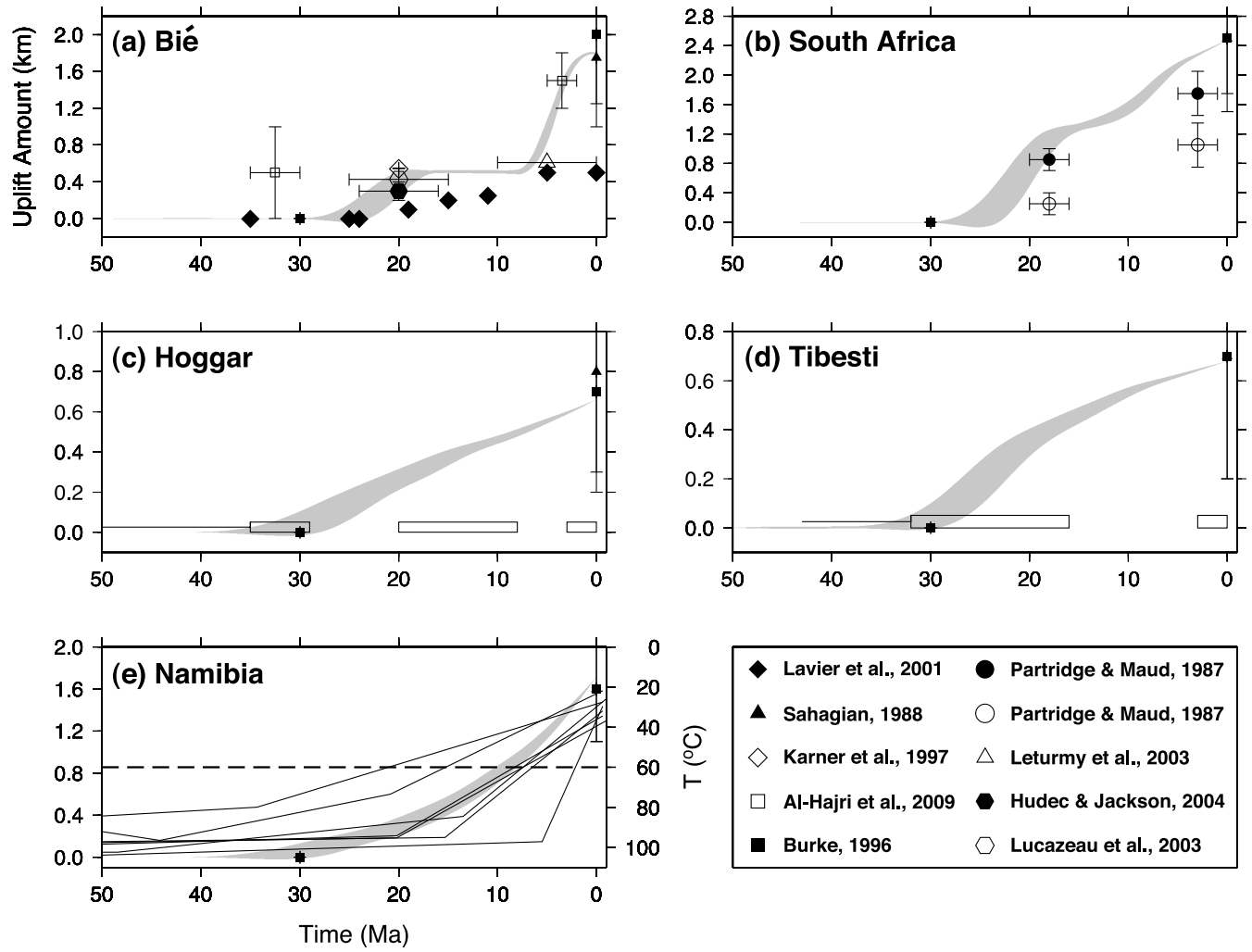

Figure 13. Comparison between predicted and published cumulative uplift histories of the five analyzed domes. (a) Bié Plateau: gray band represents cumulative uplift history calculated from Cuvo river; other symbols refer to independent uplift estimates (see key at bottom right). (b) South African Dome: gray band represents cumulative uplift history calculated from Camperdown river. Solid circles with error bars include $\sim 500 \mathrm{~m}$ of pre-Cenozoic topography dated from analysis of erosion surfaces [Partridge and Maud, 1987; Partridge, 1998]. Open circles disregard pre-Cenozoic topography. (c) Hoggar Dome: gray band represents cumulative uplift history calculated from Falesles river. (d) Tibesti Dome: gray band represents cumulative uplift history calculated from Sisse river. (e) Namibian Dome: gray band represents cumulative uplift history calculated from Ugab river. Thin black lines and righthand $y$ axis show crustal cooling estimates based upon apatite fission track analyses [Luft et al., 2005]. Horizontal dashed line represents $60{ }^{\circ} \mathrm{C}$ partial annealing zone below which annealing behavior is not well understood [Raab et al., 2005]. In Figures 13c and 13d, open boxes indicate periods of magmatic activity [Thorpe and Smith, 1974; Ashwal and Burke, 1989; Wilson and Guiraud, 1992; Gourgaud and Vincent, 2004; Liégeois et al., 2005; Permenter and Oppenheimer, 2007].

peaked in Miocene times and persisted until Quaternary times [Thorpe and Smith, 1974; Ashwal and Burke, 1989; Wilson and Guiraud, 1992]. Its spatial distribution is consistent with the locus of long-wavelength gravity and tomographic anomalies [Wilson and Guiraud, 1992]. These observations suggest that a thermal anomaly initiated beneath the Hoggar dome in Late Cretaceous-Eocene times and that this anomaly has decayed since the peak of volcanic activity in Miocene times. In the Tibesti region, Wilson and Guiraud [1992] suggest that an intense phase of volcanism started in Middle Eocene times.

[35] Observed and calculated river profiles for the Hoggar and Tibesti domes are shown in Figures 11 and 12 . Choosing a suitable reference level for these river profiles is problematic since we are far from any coastline and at an average elevation of $200-400 \mathrm{~m}$. There is no guarantee that this elevation has remained constant during domal uplift. However, the river profiles are relatively mature and we will assume that any knickpoints generated outside of the region will have propagated back to the observed profiles. Therefore we tentatively choose a local reference level for each river profile which is given by the distal profile height. The Hoggar river profiles are largely concave and do not exhibit rapid changes in gradients. Inversion of these profiles suggests that uplift started in Eocene times (40-50 Ma) and amounted to $\sim 0.2-0.5 \mathrm{~km}$. During Miocene times, the Hoggar massif was uplifted by an additional $\sim 0.4-0.6 \mathrm{~km}$. Cumulative uplift appears to have increased steadily with time and our values agree with the timing of uplift inferred from a temporal history of magmatism and from regional uplift of the calculated Cenomanian surface (Figure 13). The Tibesti river profiles show that most uplift $(0.4-1.2 \mathrm{~km})$ 

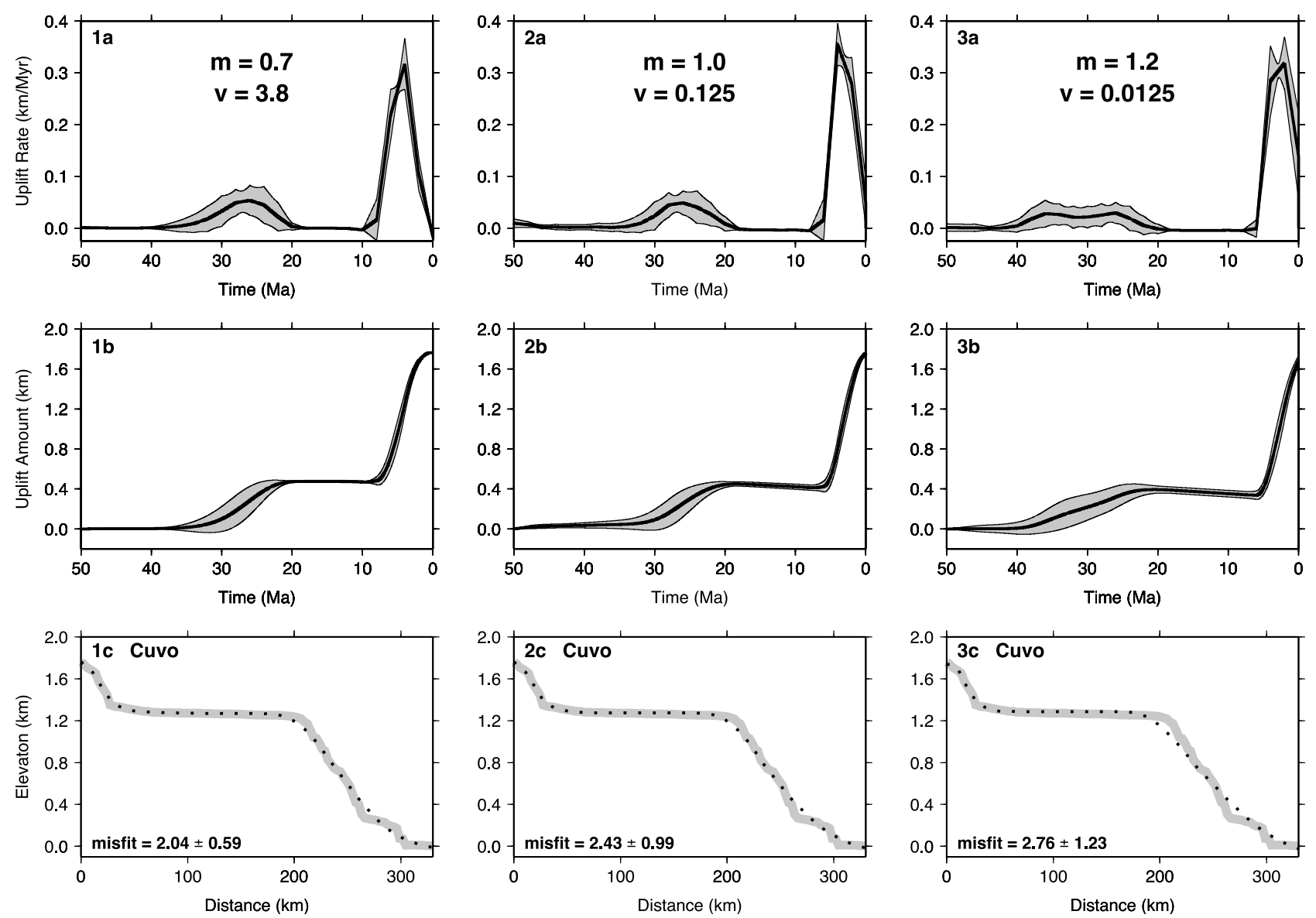

Figure 14. Sensitivity tests, which show effects of varying $m$ on calculated uplift rate histories for the Cuvo river, Bié dome. $(1 \mathrm{a}-1 \mathrm{c})$ Calculated uplift rate history, cumulative uplift, and calculated/observed river profile. Monte Carlo inversions were carried out as before with median values of $v=3.8 \mathrm{~m}^{1-m}$ $\mathrm{Myr}^{-1}, m=0.7, n=1$, and $\kappa=10^{5} \mathrm{~m}^{2} \mathrm{Myr}^{-1}$. Uncertainty bands for erosional parameters as before. (2a-2c) Monte Carlo inversions carried out with $m=1.0$ and $v=0.125$. (3a-3c) Monte Carlo inversions carried out with $m=1.2$ and $v=0.0125$. In each case, note that geologically reasonable uplift rate histories can only be obtained by varying $m$ and $v$ together.

occurred during Early Oligocene times $(\sim 30 \mathrm{Ma})$. Uplift rates were almost one order of magnitude faster than for the Hoggar dome. Since Early Miocene times, Tibesti has experienced more modest rates of uplift which generated a cumulative uplift of $<0.4 \mathrm{~km}$. These results are corroborated by the magmatic history which suggests that the main phase of dome formation occurred at $\sim 30 \mathrm{Ma}$ (Figure 13).

\section{Discussion}

[36] We have shown that a wide range of river profile shapes can be accurately fitted by varying uplift rate as a function of geologic time. Calculated uplift rate histories are corroborated by independent geologic observations. We have found that erosion along a river profile is dominated by knickpoint retreat. If $n=1$, we infer that knickpoint velocity is controlled by $v x^{m}$, where $v=50 \mathrm{~m}^{1-m} \mathrm{Myr}^{-1}$ and $m=0.5$. Therefore the concavity index, $\hat{m} / n$, is 0.25 . This value is smaller than the published range $(0.35-0.6)$. How does $U(t)$ vary if larger values of $m$ are used? In Figure 14, three sets of Monte Carlo inversions have been carried out on the Cuvo River (Bié Dome). In each set, $m=0.7,1.0$, and 1.2. If $v=50$, large residual misfits between calculated and observed river profiles are obtained, which confirms that there is trade off between $m$ and $v$ (see Figure 6). If $v=$ $1.2 \times 10^{4} \exp (-11 \mathrm{~m})$, residual misfits in all three cases are acceptable. Note that larger values of $m$ yield slightly larger residual misfits and slightly different uplift rate histories. When $m=1.2$, the younger uplift event is pushed closer toward the present-day and the older uplift event is smeared out. Provided an appropriate trade-off relationship is used, our results are not substantially altered. Finally, we have produced a convenient look-up chart which allows the timing of uplift events to be estimated from knickpoint position (Figure 15).

[37] Despite the success of our approach, we are aware that there may be serious objections to the general application of a simple inverse model. These objections can be divided into three categories. The first category concerns the drainage networks themselves. We have assumed that a single river profile, extracted from a drainage network, is representative of regional uplift. Preliminary work on the Bié Plateau suggests that consistent uplift histories can be 
Knickpoint distance from mouth, $\mathrm{km}$

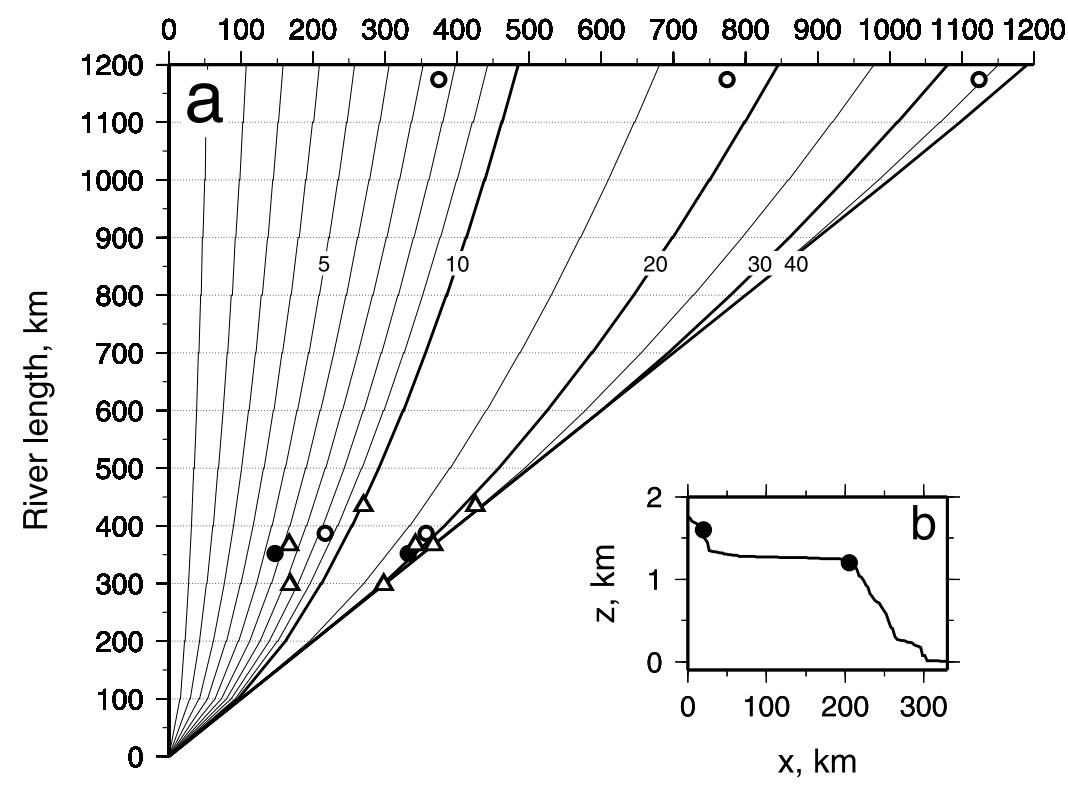

Figure 15. Look-up chart for estimating timing of uplift events directly from knickpoint distances along river profiles. Amplitude of an uplift event can be estimated from knickpoint height. Erosional parameter values are $v=50 \mathrm{~m}^{1-m} \mathrm{Myr}^{-1}, m=0.5, n=1$ and $\kappa=10^{5} \mathrm{~m}^{2} \mathrm{Myr}^{-1}$. (a) River length plotted as a function of knickpoint distance. Numbered lines are isochrons in Myrs which yield timing of uplift event for a given river length-knickpoint distance pair. Magnitude of uplift event is given by knickpoint height. Open circles represent knickpoint estimates for two rivers from Bié dome (Figure 8); open triangles represent knickpoint estimates for three rivers from South Africa dome (Figure 9); solid circles represent knickpoint estimates for Cuvo River. (b) Cuvo River, Bié dome. Solid circles are two knickpoint estimates used in Figure 15a.

extracted from a combination of trunk and tributary profiles. We also assume that the planform of a river remains fixed through time and space. In reality, rivers probably grow toward future drainage divides. Complexities associated with drainage planform such as meander and capture are also ignored. One way to deal with these different problems is to generalize our inversion algorithm so that entire drainage networks can be modeled.

[38] A second category of objections concerns uplift rate histories and reference levels. We have assumed that there is no preexisting topography and that uplift is only a function of time. Thus one-dimensional block uplift occurs and knickpoints are created at, and propagate from, the reference level alone. In reality, preexisting topography does occur and uplift evidently varies as a function of time and space. The reference level can change since sea level fluctuates although this effect is usually small when compared with cumulative uplift. Most of these complications can be addressed by varying our simplified boundary conditions. Spatial and temporal variation in uplift can be tackled by generalizing our model to invert for $U(x, y, t)$.

[39] The final category of objections is more contentious. How does the erosional process affect our results? What about changes in climate, discharge and lithology? In our view, erosion is a secondary process which modulates the effects of regional uplift. The geomorphic community is understandably more interested in the erosion and transport of rock and regolith. Thus uplift is often neglected or assumed to take a prescribed form. Our results suggest that lithology and instantaneous discharge may play a less significant role in governing the shape of a river profile. Instead, we suspect that integrated discharge and the uplift rate history are the primary controls on the transient form of a river profile. If our hypothesis is correct, drainage networks should yield valuable information about the temporal and spatial pattern of uplift rate.

\section{Conclusions}

[40] We present and test a one-dimensional inverse algorithm which calculates the uplift rate histories from river profiles. This inverse model is deliberately simple: we assume that the shape of a river profile is controlled by the uplift rate history and moderated by the erosional process. This process is parameterized by a combination of advection and diffusion which are determined by four constants. Sensitivity analysis suggests that the inverse model is stable and and well-posed. We have applied this inverse approach to African drainage patterns in order to constrain regional uplift rates. Results from the Bié, South Africa, Namibia, Hoggar, and Tibesti topographic swells agree with independently determined uplift rate histories. A maximum uplift rate of $0.4 \mathrm{~km} \mathrm{Myr}^{-1}$ was obtained for the Bié Plateau. This value is consistent with estimates of transient convective support [Rudge et al., 2008]. Our simple one-dimensional scheme can easily be generalized and applied to two- and three-dimensional topographic data. Uplift rate histories should yield useful constraints for the evolution of dynamic topography. 


\section{Appendix A: Dimensional Analysis}

[41] For convenience, the governing equation is recast in dimensionless form. If

$$
\begin{gathered}
z^{\prime}=\frac{z}{H} \\
x^{\prime}=\frac{x}{L} \\
t^{\prime}=\left(\frac{\kappa}{L^{2}}\right) t \\
U^{\prime}=\left(\frac{L}{\kappa}\right) U
\end{gathered}
$$

where $H$ and $L$ are appropriately chosen scales of elevation and length, respectively. By rearranging and substituting equations (1) and (2), we obtain

$$
\frac{\partial z^{\prime}}{\partial t^{\prime}}=\frac{-v L^{(2+m-n)} H^{(n-1)} x^{\prime m}}{\kappa}\left(\frac{\partial z^{\prime}}{\partial x^{\prime}}\right)^{n}+\frac{\partial^{2} z^{\prime}}{\partial x^{\prime 2}}+\frac{L}{H} U^{\prime}
$$

This equation has an effective Péclet number which relates the rate of upstream advection of a knickpoint to the rate of diffusion or downwearing. Thus

$$
P e=\frac{\nu L^{(2+m-n)} H^{(n-1)} x^{\prime m}}{\kappa}\left(\frac{\partial z^{\prime}}{\partial x^{\prime}}\right)^{n-1}
$$

The value of $P e$ is strongly dependent upon local slope and distance along a river profile.

\section{Appendix B: Numerical Methods}

[42] In its general form, the governing equation is not amenable to analytical attack and we have solved it using a numerical scheme. First, distance, $x$, and time, $t$, are discretized so that

$$
\begin{array}{ll}
x_{j}=x_{\circ}+j \Delta x, & j=0,1, \ldots, J \\
t_{n}=t_{\circ}+n \Delta t, & n=0,1 \ldots, N
\end{array}
$$

To solve the diffusive term, we have used the CrankNicolson scheme which is second-order accurate and stable for any $\Delta t$. Thus

$$
\frac{z_{j}^{n+1}-z_{j}^{n}}{\Delta t}=\frac{\kappa}{2}\left(\frac{\left(z_{j+1}^{n+1}-2 z_{j}^{n+1}+z_{j-1}^{n+1}\right)+\left(z_{j+1}^{n}-2 z_{j}^{n}+z_{j-1}^{n}\right)}{(\Delta x)^{2}}\right)
$$

If

$$
\alpha=\frac{\kappa \Delta t}{(\Delta x)^{2}}
$$

then equation (B2) can be rewritten as

$$
-\frac{1}{2} \alpha z_{j+1}^{n+1}+(1+\alpha) z_{j}^{n+1}-\frac{1}{2} \alpha z_{j-1}^{n+1}=\frac{1}{2} \alpha z_{j+1}^{n}+(1-\alpha) z_{j}^{n}+\frac{1}{2} \alpha z_{j-1}^{n}
$$

[43] If $z_{j}^{n}$ is known and $z_{j}^{n+1}$ is an unknown vector of length $J$, then equation (B4) can be recast in matrix form. If $x_{j}=z_{j}^{n+1}$ then

$$
\mathbf{x}=\mathbf{A}^{-1} \mathbf{r}
$$

where the matrix $\mathbf{A}$ is given by

$$
\mathbf{A}=\left(\begin{array}{ccccc}
\gamma & \gamma & 0 & 0 & \cdots \\
-\frac{1}{2} \alpha & 1+\alpha & -\frac{1}{2} \alpha & 0 & \cdots \\
0 & -\frac{1}{2} \alpha & 1+\alpha & -\frac{1}{2} \alpha & \cdots \\
\vdots & \vdots & \vdots & \vdots & \ddots
\end{array}\right)
$$

where values of $\gamma$ are determined by the boundary conditions. It is straightforward to invert this matrix. $x_{n}$ (i.e., $z_{j}$ ) can be rewritten as

$$
\left(\begin{array}{c}
x_{\circ} \\
x_{1} \\
\ldots \\
x_{J-1} \\
x_{J}
\end{array}\right)=\left(\begin{array}{ccccccc}
b_{\circ} & c_{\circ} & 0 & \ldots & & & \\
a_{1} & b_{1} & c_{1} & \ldots & & & \\
& & & \ldots & & & \\
& & & \ldots & a_{J-1} & b_{J-1} & c_{J-1} \\
& & & \ldots & 0 & a_{J} & b_{J}
\end{array}\right)^{-1}\left(\begin{array}{c}
r_{\circ} \\
r_{1} \\
\ldots \\
r_{J-1} \\
r_{J}
\end{array}\right)
$$

where $b_{\circ}=1, c_{\circ}=0, r_{\circ}=z(0), a_{J}=0, b_{J}=1$, and $r_{J}=z(L)$. $a_{j}=c_{j}=-\frac{1}{2} \alpha, b_{j}=1+\alpha$, and $r_{j}=\frac{1}{2} \alpha z_{j+1}^{n}-\alpha z_{j}^{n}+\frac{1}{2} \alpha z_{j-1}^{n}$ for $1 \leq j \leq J-1$. The top and bottom rows of $\mathbf{A}$ are used to apply boundary conditions.

[44] To solve the advective term, we use an upwind differencing scheme. Thus

$$
\frac{z_{j}^{n+1}-z_{j}^{n}}{\Delta t}=-v x^{m}\left(-\frac{z_{j+1}^{n}-z_{j}^{n}}{\Delta x}\right)^{n}
$$

The stability criterion is given by

$$
\frac{\left|v x^{m}\left(-\frac{z_{i+1}^{n}-z_{j}^{n}}{\Delta x}\right)^{n-1}\right| \Delta t}{\Delta x} \leq 1
$$

In practice, the steepest slope $\left(z_{j+1}^{n}-z_{j}^{n}\right) / \Delta x$ is used to set the step size required for stability. The two numerical schemes are combined using the operator-splitting technique. See Press et al. [1992] for further details. 


\section{Notation}

$z$ elevation of river [L].

$x$ distance along river [L].

$t$ time [T].

$U$ uplift rate $\left[\mathrm{L} \mathrm{T}^{-1}\right]$.

$E$ erosion rate $\left[\mathrm{L} \mathrm{T}^{-1}\right]$.

$v$ advective coefficient of erosion $\left[\mathrm{L}^{1-m} \mathrm{~T}^{-1}\right]$.

$m$ distance exponent, dimensionless.

$\hat{m}$ distance exponent in literature, dimensionless.

$n$ slope exponent, dimensionless.

$\kappa$ diffusive coefficient of erosion $\left[\mathrm{L}^{2} \mathrm{~T}^{-1}\right]$.

$\sigma$ variance of data [L].

$W_{1}$ weighting coefficient, penalizing slope of $U$, dimensionless.

$W_{2}$ weighting coefficient, penalizing second derivative of $U$, dimensionless.

$W_{3}$ weighting coefficient, penalizing negative $U$, dimensionless.

$N$ number of measurements of $z$, dimensionless.

$U_{k}$ value of $U$ at discrete intervals, $\left[\mathrm{L} \mathrm{T}^{-1}\right]$.

$M$ number of $U_{k}$ values, dimensionless.

$z^{\prime}$ dimensionless elevation of river.

$x^{\prime}$ dimensionless distance along river.

$t^{\prime}$ dimensionless time.

$U^{\prime}$ dimensionless uplift rate.

$H$ elevation scale [L].

$L$ distance scale [L].

$P_{e} \quad$ Péclet number, dimensionless.

[45] Acknowledgments. GGR is supported by BP Exploration and by the University of Cambridge. We thank A. Crosby, G. Edwards, N. Hovius, J. Hoyes, B. Lovell, D. Lyness, J. Maclennan, E. Nissen, S. Nixon, D. Pritchard, C. Richardson, J. Rudge, and J. Winterbourne for their generous help. Two anonymous reviewers and the associate editor provided valuable comment and advice. Figures were made using GMT 3.4.5 and ArcView. Department of Earth Sciences contribution ES.1176.

\section{References}

Al-Hajri, Y. K., N. White, and S. Fishwick (2010), Scales of transient convective support beneath west Africa, Geology, in press.

Amos, C. B., and D. W. Burbank (2007), Channel width response to differential uplift, J. Geophys. Res., 112, F02010, doi:10.1029/2006JF000672.

Ashwal, L. D., and K. Burke (1989), African lithospheric structure, volcanism, and topography, Earth Planet. Sci. Lett., 96, 8-14.

Baldwin, J. A., K. X. Whipple, and G. E. Tucker (2003), Implications of the shear stress river incision model for the timescale of postorogenic decay of topography, J. Geophys. Res., 108(B3), 2158, doi:10.1029/ 2001JB000550.

Bishop, P. (2007), Long-term landscape evolution: Linking tectonics and surface processes, Earth Surf. Processes Landforms, 32, 329-365.

Bray, R., and S. Lawrence (1999), Nearby finds brighten outlook for Equatorial Guinea and Namibia, Oil Gas J., 97(5), 67-75.

Bray, R., S. Lawrence, and R. Swart (1998), Source rock, maturity data indicate potential off Namibia, Oil Gas J., 96(32), 84-89.

Brown, R. W., M. A. Summerfield, and A. J. W. Gleadow (2002), Denudation history along a transect across the Drakensberg Escarpment of southern Africa derived from apatite fission track thermochronology, J. Geophys. Res., 107(B12), 2350, doi:10.1029/2001JB000745.

Burke, K. (1996), The African plate, S. Afr. J. Geol., 99(4), 341-409.

Burke, K., and Y. Gunnell (2008), The African erosion surface: A continetalscale synthesis of geomorphology, tectonics, and environmental change over the past 180 million years, Geol. Soc. Am. Mem., 201, 72 pp.

Choubert, G., and A. Faure-Muret (1990), Geological World Atlas, Int. Geol. Map. Bur., UNESCO, Paris.

Cramez, C., and M. P. A. Jackson (2000), Superposed deformation staddling the continental-oceanic transition in deep-water Angola, Mar. Petrol. Geol., 17, 1095-1109.

Crosby, B. T., and K. X. Whipple (2006), Knickpoint initiation and distribution within fluvial networks: 236 waterfalls in the Waipaoa River, North Island, New Zealand, Geomorphology, 82, 16-38.
Davis, W. M. (1899), The geographical cycle, Geogr. J., 14, 481-504.

de Wit, M. C. J. (1999), Post-Gondwana drainage and the development of diamond placers in western South Africa, Econ. Geol. Bull. Soc. Econ. Geol., 94, 721-740.

Dupont, L. M., B. Donner, L. Vidal, E. M. Pérez, and G. Wefer (2005), Linking desert evolution and coastal upwelling: Pliocene climate change in Namibia, Geology, 33(6), 461-464.

Duvall, A., E. Kirby, and D. Burbank (2004), Tectonic and lithologic controls on bedrock channel profiles and processes in coastal California, J. Geophys. Res., 109, F03002, doi:10.1029/2003JF000086.

England, P., and J. Jackson (1989), Active deformation of continents, Annu. Rev. Earth Planet. Sci., 17, 197-226.

Farr, T. G., et al. (2007), The Shuttle Radar Topographic Mission, Rev Geophys., 45, RG2004, doi:10.1029/2005RG000183.

Gallagher, K., and R. Brown (1999), The Mesozoic denudation history of the Atlantic margins of southern Africa and southeast Brazil and the relationship to offshore sedimentation, in The Oil and Gas Habitats of the South Atlantic, edited by N. R. Cameron et al., Geol. Soc. London Spec. Publ., 153, 41-53.

Gasparini, N. M., K. X. Whipple, and R. L. Bras (2007), Predictions of steady state and transient landscape morphology using sediment-fluxdependent river incision models, J. Geophys. Res., 112, F03S09, doi:10.1029/2006JF000567.

Gourgaud, A., and P. M. Vincent (2004), Petrology of two continental alkaline intraplate series at Emi Koussi volcano, Tibesti, Chad, J. Volcanol. Geotherm. Res., 129, 261-290.

Hack, J. T. (1957), Studies of longitudinal stream profiles in Virginia and Maryland, U.S. Geol. Surv., 1, 421-429.

Hack, J. T. (1975), Dynamic equilibrium and landscape evolution, in Theories of Landscape Evolution, edited by W. N. Melhorn and R. C. Flemal, Allen and Unwin, Boston, Mass.

Hancock, G. R., C. Martinez, K. G. Evans, and D. R. Moliere (2006), A comparison of SRTM and high-resolution digital elevation models and their use in catchment geomorphology and hydrology: Australian examples, Earth Surf. Processes Landforms, 31, 1394-1412.

Hartley, R., A. B. Watts, and J. D. Fairhead (1996), Isostasy of Africa, Earth Planet. Sci. Lett., 137, 1-18.

Hovius, N. (1998), Controls on sediment supply by large rivers, in Relative Role of Eustasy, Climate, and Tectonism in Continental Rocks, edited by K. W. Shanley and P. J. McCabe, SEPM Spec. Publ., 59, 3-16.

Howard, A., M. Seidl, and W. Dietrich (1994), Modeling fluvial erosion on regional to continental scales, J. Geophys. Res., 99, 13,971-13,986.

Humphrey, N. F., and S. K. Konrad (2000), River incision or diversion in response to bedrock uplift, Geology, 28(1), 43-46.

Jackson, M. P. A., M. R. Hudec, and K. A. Hegarty (2005), The great West African Tertiary coastal uplift: Fact or fiction? A perspective from the Angolan divergent margin, Tectonics, 24, TC6014, doi:10.1029/ 2005TC001836.

King, L. (1962), The Morphology of the Earth: A Study and Synthesis of World Scenery, Oliver and Boyd, London.

Kirby, E., and K. Whipple (2001), Quantifying differential rock-uplift rates via stream profile analysis, Geology, 29(5), 415-418.

Kooi, H., and C. Beaumont (1994), Escarpment evolution on high-elevation rifted margins: Insights derived from a surface process model that combines diffusion, advection, and reaction, J. Geophys. Res., 99(B6), $12,191-12,209$

Lague, D., and P. Davy (2003), Constraints on the long-term colluvial erosion law by analysing slope-area relationships at various tectonic uplift rates in the Siwalik Hills (Nepal), J. Geophys. Res., 108(B2), 2129, doi:10.1029/2002JB001893.

Lavé, J., and J. P. Avouac (2001), Fluvial incision and tectonic uplift across the Himalayas of central Nepal, J. Geophys. Res., 106, 26,561-26,591.

Lesquer, A., A. Bourmatte, S. Ly, and J. M. Dautria (1989), First heat flow determination from central Sahara: relationship with the Pan-African belt and Hoggar domal uplift, J. Afr. E. Sci., 9(1), 41-48.

Leturmy, P., F. Lucazeau, and F. Brigaud (2003), Dynamic interations between the gulf of Guinea passive margin and the Congo River drainage basin: 1. Morphology and mass balance, J. Geophys. Res., 108(B8), 2383, doi:10.1029/2002JB001927.

Liégeois, J. P., A. Benhallou, A. Azzouni-Sekkal, R. Yahiaoui, and B. Bonin (2005), The Hoggar swell and volcanism: Reactivations of the Precambrian Tuareg shield during Alpine convergence and West African Cenozoic volcanism, in Plates, Plumes and Paradigms, edited by G. R. Foulger et al., Geol. Soc. Am. Spec. Pap., 388, 379-400.

Lucazeau, F., F. Brigaud, and P. Leturmy (2003), Dynamic interations between the gulf of Guinea passive margin and the Congo River drainage basin: 2. Isostasy and uplift, J. Geophys. Res., 108(B8), 2384, doi:10.1029/2002JB001928. 
Luft, F. F., J. F. Chemale, L. M. V. M.Lelarge, and J. N. Avila (2005), PostGondwana break-up record constraints from apatite fission track thermochronology in NW Namibia, Radiat. Meas., 39, 675-679.

Maslanyj, M. P., M. P. R. Light, R. J. Greenwood, and N. L. Banks (1992), Extension tectonics offshore Namibia and evidence for passive rifting in the South Atlantic, Mar. Petrol. Geol., 9, 590-601.

Miller, K. G., M. A. Kominz, J. V. Browning, J. D. Wright, G. S. Mountain M. E. Katz, P. J. Sugarman, B. S. Cramer, N. Christie-Blick, and S. F. Pekar (2005), The Phanerozoic record of global sea-level change, Science, 310(5752), 1293-1298, doi:10.1126/science.1116412.

Molnar, P., and H. Lyon-Caen (1988), Some simple physical aspects of the support, structure, and evolution of mountain belts, in Processes in Continental and Lithospheric Deformation, edited by S. P. Clark Jr., Geol. Soc. Am. Spec. Pap., 218.

Nicholson, S. E. (2000), The nature of rainfall variability over Africa on time scales of decades to millenia, Global Planet. Change, 26(1-3), 137-158, doi:10.1016/S0921-8181(00)00040-0.

Nyblade, A. A., and S. W. Robinson (1994), The African Superswell, Geophys. Res. Lett., 21, 765-768.

Partridge, T. C. (1998), Of diamonds, dinosaurs and diatrophism: 150 million years of landscape evolution in southern Africa, S. Afr. J. Geol., 101(3), $161-184$.

Partridge, T. C., and R. R. Maud (1987), Geomorphic evolution of southern Africa since the Mesozoic, S. Afr. J. Geol., 90(2), 179-208.

Peizhen, Z., P. Molnar, and W. Downs (2001), Increased sedimentation rates and grain sizes 2-4 Myr ago due to the influence of climate change on erosion rates, Nature, 410, 891-897.

Penck, W. (1953), Morphological Analysis of Landforms, Macmillan, London.

Penck, W. (1972), Morphological Analysis of Landforms: A Contribution to Physical Geology, translated from German by H. Czech and K. C. Boswell, Hafner, New York.

Permenter, J. L., and C. Oppenheimer (2007), Volcanoes of the Tibesti massif (Chad, northern Africa), Bull. Volcanol., 69, 609-626.

Press, W. H., S. A. Teukolsky, W. T. Vetterling, and B. P. Flannery (1992), Numerical Recipies in FORTRAN: The Art of Scientific Computing, 2nd ed., Cambridge Univ. Press, New York.

Raab, M. J., R. W. Brown, K. Gallagher, K. Weber, and A. J. W. Gleadow (2005), Denudational and thermal history of the Early Cretaceous Brandberg and Okenyenya igneous complexes on Namibia's Atlantic passive margin, Tectonics, 24, TC3006, doi:10.1029/2004TC001688.

Ritsema, J., H. J. van Heijst, and J. H. Woodhouse (1999), Complex shear wave velocity stucture imaged beneath Africa and Iceland, Science, 286, $1925-1928$

Rosenbloom, N. A., and R. S. Anderson (1994), Hillslope and channel evolution in a marine terraced landscape, Santa Cruz, Califonia, J. Geophys. Res., 99(B7), 14,013-14,029.

Rudge, J. F., M. E. Shaw Champion, N. White, D. McKenzie, and B. Lovell (2008), A plume model of transient diachronous uplift at the Earth's surface, Earth Planet. Sci. Lett., 267(1-2), 146-160.

Sahagian, D. (1988), Epeirogenic motions of Africa as inferred from Cretaceous shoreline deposits, Tectonics, 7(1), 125-138.

Schoenbohm, L. M., K. X. Whipple, B. C. Burchfiel, and L. Chen (2004), Geomorphic constraints on surface uplift, exhumation, and plateau growth in the Red River region, Yunnan Province, China, Geol. Soc. Am. Bull., 116(7/8), 895-909.

Sklar, L. S., and W. E. Dietrich (2001), Sediment and rock strength controls on river incision into bedrock, Geology, 29(12), 1087-1090.

Snyder, N. P., K. X. Whipple, G. E. Tucker, and D. J. Merritts (2000), Landscape response to tectonic forcing: Digital elevation model analysis of stream profiles in the Mendocino triple junction region, northern California, Geol. Soc. Am. Bull., 112(8), 1250-1263.
Snyder, N. P., K. X. Whipple, G. E. Tucker, and D. J. Merritts (2003), Importance of stochastic distribution of floods and erosion thresholds in the bedrock river incision problem, J. Geophys. Res., 108(B2), 2117 , doi:10.1029/2001JB001655.

Syvitski, J. P. M., and J. D. Milliman (2007), Geology, geography, and humans battle for dominance over the delivery of fluvial sediment to the coastal ocean, J. Geol., 115, 1-19.

Tapley, B., et al. (2005), GGM02 - An improved Earth gravity field model from GRACE, J. Geod., 79(8), 467-478.

Thorpe, R. S., and K. Smith (1974), Distribution of Cenozoic volcanism in Africa, Earth Planet. Sci. Lett., 22, 91-95.

Tomkin, J. H., M. T. Brandon, F. J. Pazzaglia, J. R. Barbour, and S. D. Willett (2003), Quantitative testing of bedrock incision models for the Clearwater River, NW Washington State, J. Geophys. Res., 108(B6), 2308, doi:10.1029/2001JB000862.

Tucker, G. E., and K. X. Whipple (2002), Topographic outcomes predicted by stream erosion models: Sensitivity analysis and intermodel comparison, J. Geophys. Res., 107(B9), 2179, doi:10.1029/2001JB000162.

Turowski, J., D. Lague, A. Crave, and N. Hovius (2006), Experimental channel response to tectonic uplift, J. Geophys. Res., 111, F03008, doi:10.1029/2005JF000306.

van der Beek, P., M. A. Summerfield, J. Braun, R. W. Brown, and A. Fleming (2002), Modelling postbreakup landscape development and denudational history across the southeast African (Drakensberg Escarpment) margin, J. Geophys. Res., 107(B12), 2351, doi:10.1029/ 2001JB000744.

Walford, H., N. White, and J. Sydow (2005), Solid sediment load history of the Zambezi Delta, Earth Planet. Sci. Lett., 238, 49-63.

Weissel, J. K., and M. A. Seidl (1998), Inland propagation of erosional escarpments and river profile evolution across the southeast Australian Passive Continental Margin, in Rivers Over Rock: Fluvial Processes in Bedrock Channels, Geophys. Monogr. Ser., vol. 107, edited by T. J. Tinkler and E. E. Wohl, pp. 189-206, AGU, Washington, D. C.

Whipple, K. X., and G. E. Tucker (1999), Dynamics of the stream-power river incision model: Implications for height limits of mountain ranges, landscape response timescales, and research needs., J. Geophys. Res., 104(B8), 17,661-17,674

Whipple, K. X., and G. E. Tucker (2002), Implications of sediment-flux dependent river incision models for landscape evolution, J. Geophys. Res., 107(B2), 2039, doi:10.1029/2000JB000044.

Whittaker, A. C., M. Attal, P. Cowie, G. E. Tucker, and G. Roberts (2008), Decoding temporal and spatial patterns of fault uplift using transient river long profiles, Geomorphology, 100, 506-526.

Willgoose, G. (2005), Mathematical modeling of whole landscape evolution, Annu. Rev. Earth Planet. Sci., 33, 443-459.

Wilson, M., and R. Guiraud (1992), Magmatism and rifting in Western and Central Africa, from Late Jurassic to Recent times, Tectonophysics, 213, $203-225$

Winterbourne, J., A. Crosby, and N. White (2010), Depth, age and dynamic topography of oceanic lithosphere beneath heavily sedimented Atlantic margins, Earth Planet. Sci. Lett., in press.

Wobus, C., K. K. X. Whipple, E. Kirby, N. Snyder, J. Johnson, K. Spyropolou, B. Crosby, and D. Sheehan (2006a), Tectonic from topography: Procedures, promise, and pitfalls, Geol. Soc. Am. Spec. Pap., 398, 55-74.

Wobus, C., G. E. Tucker, and R. S. Anderson (2006b), Self-formed bedrock channels, Geophys. Res. Lett., 33, L18408, doi:10.1029/2006GL027182.

G. G. Roberts and N. White, Bullard Laboratories, Department of Earth Sciences, University of Cambridge, Madingley Rise, Madingley Road, Cambridge CB3 0EZ, UK. (ggr22@cam.ac.uk; NJW10@cam.ac.uk) 